\title{
Characterization of the Marcellus Shale Based on Computer-Assisted Correlation of Wireline Logs in Virginia and West Virginia
}

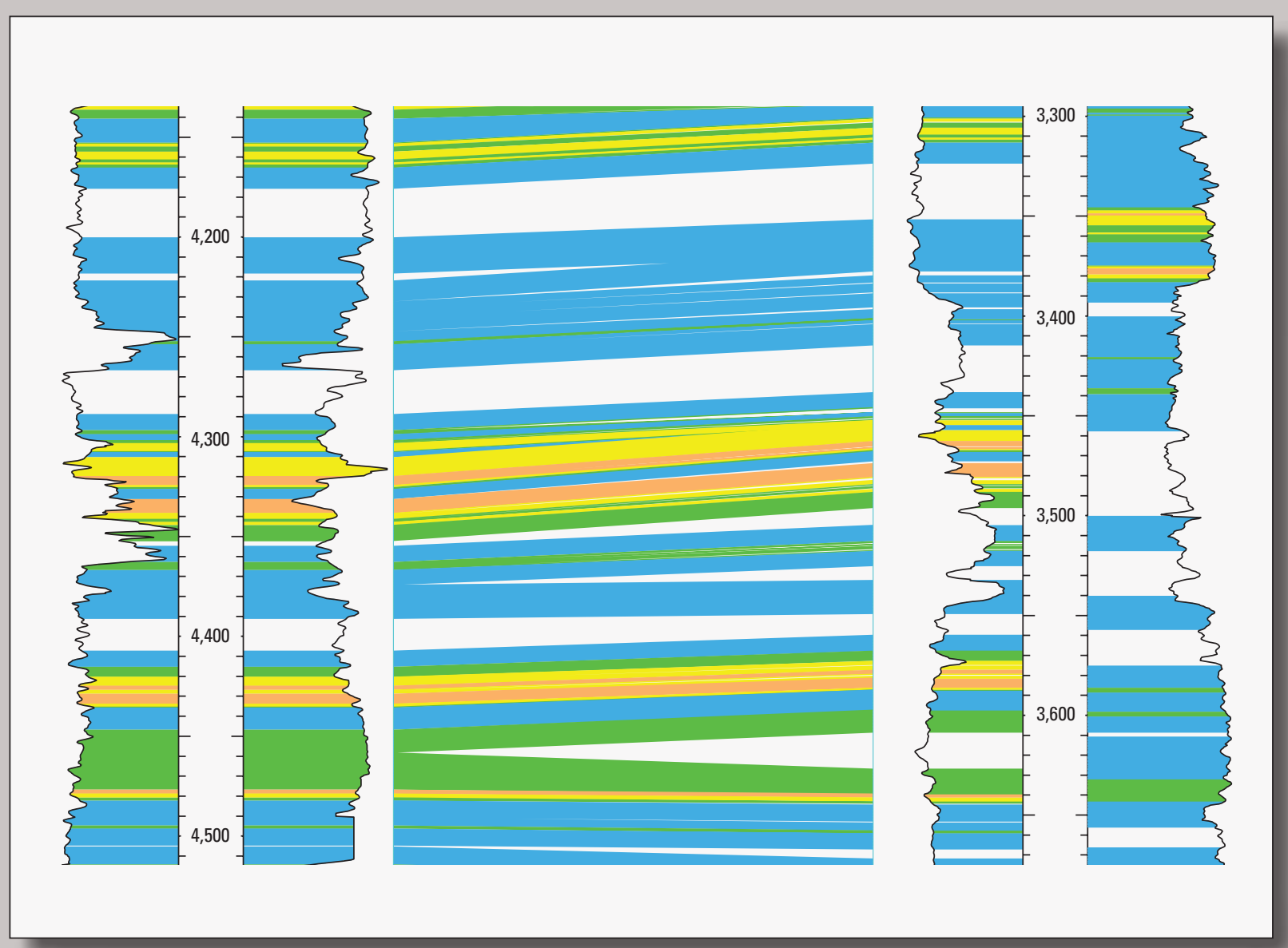

Scientific Investigations Report 2013-5131 
Cover. An example of correlation strength between two well logs (each with accompanying gamma-ray and bulk-density data), determined using the Correlator 5.2 program. Colors indicate correlation strength in percent, blue to orange being weakest to strongest, respectively. 


\section{Characterization of the Marcellus Shale Based on Computer-Assisted Correlation of Wireline Logs in Virginia and West Virginia}

By Catherine B. Enomoto, Ricardo A. Olea, and James L. Coleman, Jr.

Scientific Investigations Report 2013-5131 


\title{
U.S. Department of the Interior SALLY JEWELL, Secretary
}

\section{U.S. Geological Survey Suzette M. Kimball, Acting Director}

\author{
U.S. Geological Survey, Reston, Virginia: 2014
}

For more information on the USGS - the Federal source for science about the Earth, its natural and living resources, natural hazards, and the environment, visit http://www.usgs.gov or call 1-888-ASK-USGS.

For an overview of USGS information products, including maps, imagery, and publications, visit http://www.usgs.gov/pubprod

To order this and other USGS information products, visit http://store.usgs.gov

Any use of trade, firm, or product names is for descriptive purposes only and does not imply endorsement by the U.S. Government.

Although this information product, for the most part, is in the public domain, it also may contain copyrighted materials as noted in the text. Permission to reproduce copyrighted items must be secured from the copyright owner.

Suggested citation:

Enomoto, C.B., Olea, R.A., and Coleman, J.L., Jr., 2014, Characterization of the Marcellus Shale based on computerassisted correlation of wireline logs in Virginia and West Virginia: U.S. Geological Survey Scientific Investigations Report 2013-5131, 21 p., available at http://dx.doi.org/10.3133/sir20135131.

ISSN 2328-0328 (online) 


\section{Contents}

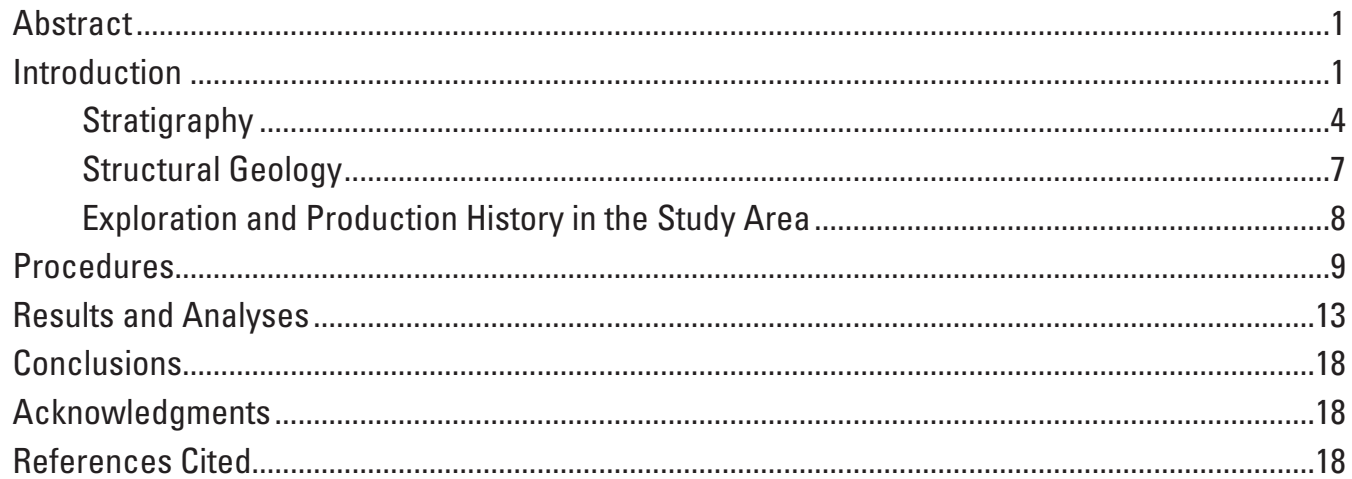

\section{Plates}

[As separate files; click link to access]

1. Wireline well logs through Middle Devonian shales in Highland and Rockingham Counties, Virginia, and Pendleton and Hardy Counties, West Virginia

2. Cross section created by the Correlator program on the basis of calculated correlation strength between well wireline logs through Middle Devonian shales in Highland and Rockingham Counties, Virginia, and Pendleton and Hardy Counties, West Virginia

3. Cross section created by the Correlator program by recoding correlation strength in plate 2 to denote stratigraphic intervals using well wireline logs through Middle Devonian shales in Highland and Rockingham Counties, Virginia, and Pendleton and Hardy Counties, West Virginia

4. Cross section created by the Correlator program on the basis of persistent correlation strength between well wireline logs through Middle Devonian shales in Highland and Rockingham Counties, Virginia, and Pendleton and Hardy Counties, West Virginia

\section{Figures}

1. Map of the study area showing the assessment units from the recent assessment of undiscovered oil and gas resources in the Devonian Marcellus Shale, the thickness of radioactive black shale in the undivided Marcellus Shale and Skaneateles Shale, and the apparent thickness of the Millboro Shale interpreted from the nine wireline logs included in this study............2

2. Photograph of a third-order fold in the Brallier Formation in Hampshire County, West Virginia.

3. Map showing regional structural geology of eastern West Virginia and western Virginia, including major tectonic features, the location of the cross section shown on figure 4 , and the location of the study area shown in figure 7 .

4. Cross section across Broadtop synclinorium and Nittany anticlinorium illustrating first- and third-order folds within middle and lower

Paleozoic strata 
5. Schematic stratigraphic chart showing Lower Devonian to Upper Devonian strata of the central Valley and Ridge and Appalachian Plateaus provinces in western Virginia and eastern West Virginia.

6. Digital wireline log curves for the Fulk No. 1 well illustrating the initial interpretation for locating the tops of the Millboro Shale, Needmore Shale, and Oriskany Sandstone using the criteria described in the text

7. Map of study area showing the outcrop area of the Middle Devonian Marcellus Shale or Millboro Shale with Needmore Shale or Huntersville Chert, regional faults, and the locations of the nine wells used in this study and the cross sections

8. Wireline log showing gamma-ray and dipmeter measurements in well HI-0004, Highland County, Virginia.

\section{Tables}

1. Wells used in this study .3

2. Apparent thickness of interpreted intervals estimated from wireline logs

3. Percentage of the interval where correlation strength between well pairs exceeded 60 percent.

4. Mean gamma-ray values, calculated for each interval.

5. Mean bulk-density values calculated for each interval..

\section{Conversion Factors}

\begin{tabular}{lcl}
\hline \multicolumn{1}{c}{ Multiply } & \multicolumn{1}{c}{ By } & \multicolumn{1}{c}{ To obtain } \\
\hline & Length & \\
\hline foot $(\mathrm{ft})$ & 0.3048 & meter $(\mathrm{m})$ \\
meter $(\mathrm{m})$ & 3.281 & foot $(\mathrm{ft})$ \\
kilometer $(\mathrm{km})$ & 0.6214 & mile $(\mathrm{mi})$ \\
\hline & Volume & \\
\hline cubic foot $\left(\mathrm{ft}{ }^{3}\right)$ & 0.02832 & cubic meter $\left(\mathrm{m}^{3}\right)$ \\
\hline & Density & \\
\hline gram per cubic centimeter $\left(\mathrm{g} / \mathrm{cm}^{3}\right.$, & 62.4220 & pound per cubic foot $\left(\mathrm{lb} / \mathrm{ft}^{3}\right)$ \\
or g/cc) & & \\
\hline
\end{tabular}

Gas volume measurements are shown using the standard industry abbreviations of MMCF (millions of cubic feet) or BCF (billions of cubic feet). 


\title{
Characterization of the Marcellus Shale Based on Computer-Assisted Correlation of Wireline Logs in Virginia and West Virginia
}

\author{
By Catherine B. Enomoto, Ricardo A. Olea, and James L. Coleman, Jr.
}

\section{Abstract}

The Middle Devonian Marcellus Shale in the Appalachian basin extends from central Ohio on the west to eastern New York on the east, and from north-central New York on the north to northern Tennessee on the south. Its thickness ranges from 0 feet ( $\mathrm{ft}$ ) where it pinches out to the west to as much as $700 \mathrm{ft}$ in its eastern extent. Within the Broadtop synclinorium, the thickness of the Marcellus Shale ranges from 250 to $565 \mathrm{ft}$. Although stratigraphic complexities have been documented, a significant range in thickness most likely is because of tectonic thickening from folds and thrust faults. Outcrop studies in the Valley and Ridge and Appalachian Plateaus provinces illustrate the challenges of interpreting the relation of third-order faults, folds, and "disturbed" zones to the regional tectonic framework. Recent field work within the Valley and Ridge province determined that significant faulting and intraformational deformation are present within the Marcellus Shale at the outcrop scale. In an attempt to determine if this scale of deformation is detectable with conventional wireline logs, petrophysical properties (primarily mineralogy and porosity) were measured by interpretation of gamma-ray and bulk-density logs. The results of performing a statistical correlation of wireline logs from nine wells indicated that there are discontinuities within the Millboro Shale (undifferentiated Marcellus Shale and Mahantango Formation) where there are significant thickness differences between wells. Also, some intervals likely contain mineralogy that makes these zones more prone to layer-shortening cleavage duplexes. The Correlator program proved to be a useful tool in a region of contractional deformation.

\section{Introduction}

Many of the geologists who mapped the eastern Appalachian basin collectively described the Marcellus Shale as a dark-gray to black, thinly laminated, fissile, pyritic shale with interbeds of dark-gray, argillaceous limestone or calcareous shale, containing limestone concretions and sparse fossils
(Dean and others, 1985; Hasson and Dennison, 1988; Schultz, 1997; Rader and Gathright, 2001). The regional thickness of the Marcellus Shale ranges from 0 feet $(\mathrm{ft})$ where it pinches out in east-central Ohio and western West Virginia to as much as $700 \mathrm{ft}$ in southeastern New York (Roen, 1984; Milici and Swezey, 2006; Boyce and Carr, 2009; Ohio Department of Natural Resources, 2010; Smith and Leone, 2010). Within the Broadtop synclinorium (Jacobeen and Kanes, 1974), geologists estimated that the thickness of the Marcellus Shale ranged from 250 to $565 \mathrm{ft}$ (Rader and Gathright, 2001; Rader and others, 2001; Enomoto, 2009) (fig. 1). The range of the measurements is most likely the result of folding and faulting within the Middle to Upper Devonian shale, especially within the Valley and Ridge province (fig. 2); also, Roen (1984) reported the thickness of radioactive black shale in the undivided Skaneateles Shale and Marcellus Shale (fig. 1), whereas Enomoto (2009) reported the uncorrected wireline log thickness of the Millboro Shale (tables 1, 2).

The Valley and Ridge province of the central Appalachian basin is characterized by thin-skinned structural deformation (Rich, 1934; Rodgers, 1949, 1963); the locations of two of the major décollements underlying the Valley and Ridge are interpreted to be within shale of the Lower Cambrian Rome Formation and Upper Ordovician Martinsburg Formation (Harris and Milici, 1977). Another major décollement exists southwest of the study area in Middle to Upper Devonian shale (Rich, 1934; Harris and Milici, 1977; Kulander and Dean, 1986). The regional map showing structural features and the cross section of Kulander and Dean (1986) (figs. 3, 4) depict the overall structural style of the western Valley and Ridge province. The cross section traverses west to east from Pocahontas County, West Virginia, to Augusta County, Virginia, and provides a point of reference for the structural features included in the study area.

Formations consisting of mostly shale and mudstone and commonly exhibiting structures indicative of ductile deformation are associated with the major folds caused by the movement on these décollement surfaces. Nickelsen (1963) defined folds with wavelengths between 7 and 10 miles (mi) as "firstorder folds," folds with wavelengths between 1.5 and $2 \mathrm{mi}$ as 


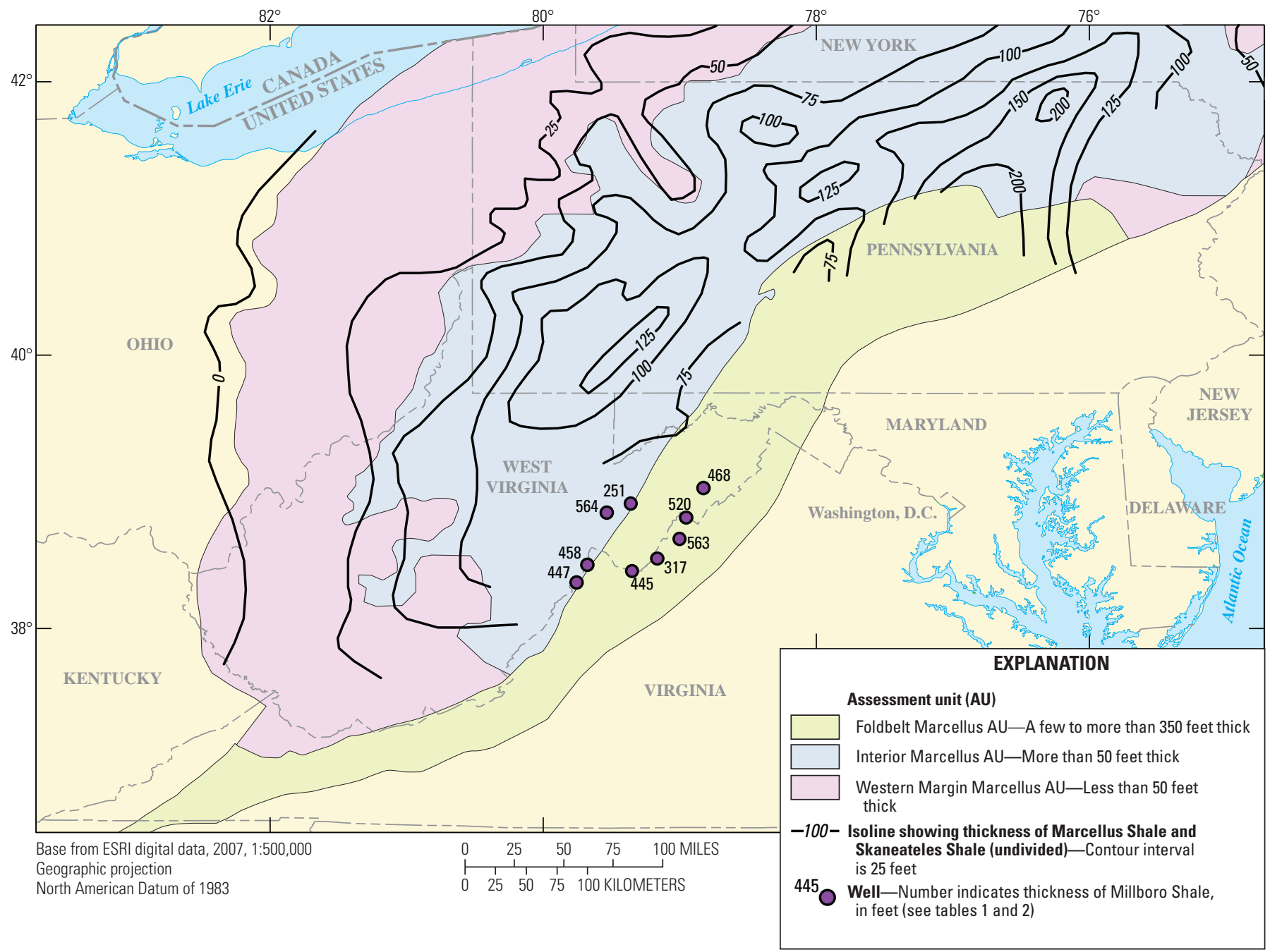

Figure 1. Map of the study area showing the assessment units from the recent assessment of undiscovered oil and gas resources in the Devonian Marcellus Shale (Coleman and others, 2011; U.S. Geological Survey, 2011), the thickness of radioactive black shale in the undivided Marcellus Shale and Skaneateles Shale (Roen, 1984), and the apparent thickness of the Millboro Shale interpreted from the nine wireline logs included in this study (Enomoto, 2009). Contour lines are in feet (ft). 


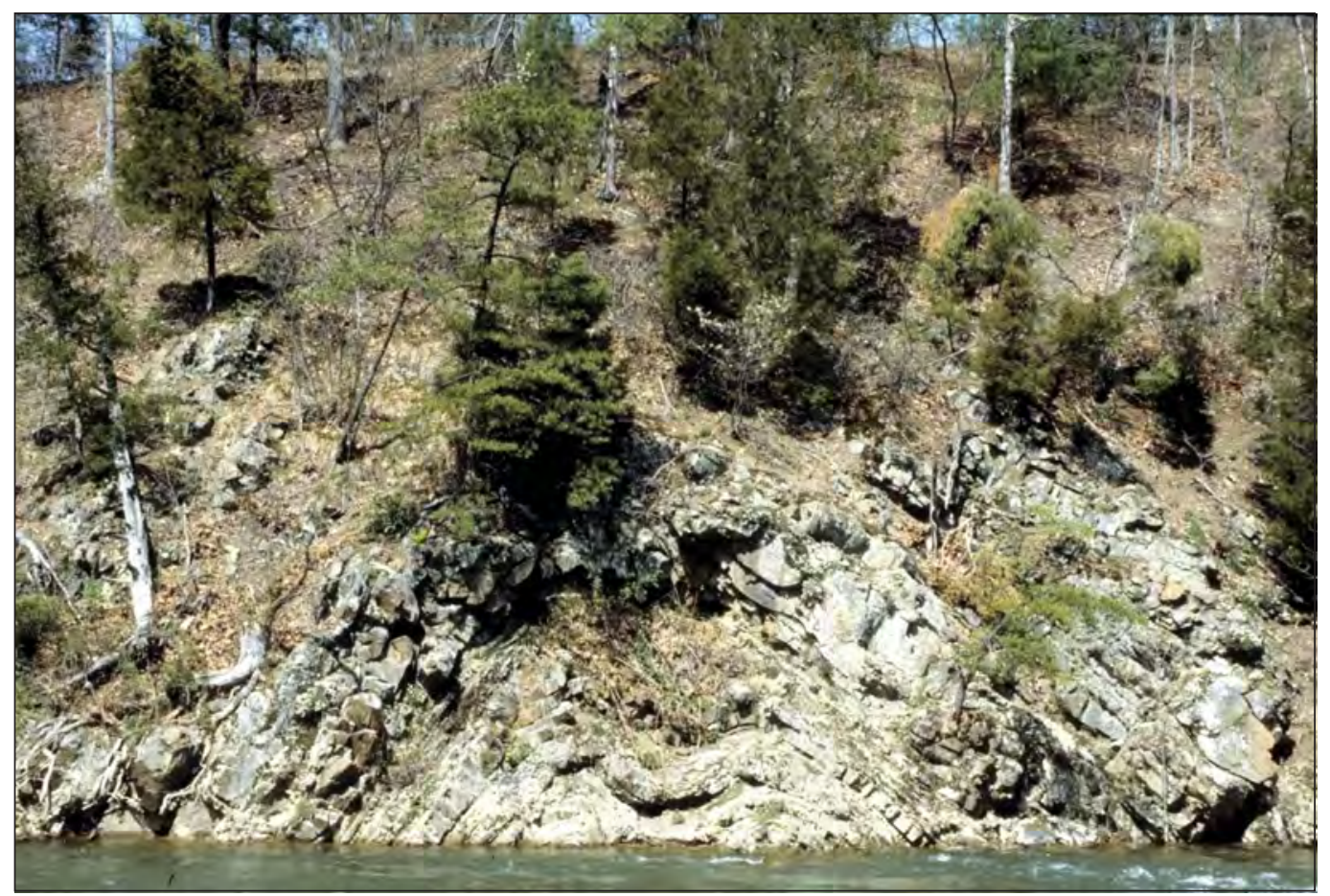

Figure 2. Photograph of a third-order fold in the Brallier Formation in Hampshire County, West Virginia. This fold is typical of those found in Devonian shale in the Valley and Ridge province. The location is approximately 350 feet northeast of the ford over the Cacapon River by Dave Mooreland Road, approximately 2 miles from the village of Levels (approximate location lat $39^{\circ} 28^{\prime} 17^{\prime \prime} \mathrm{N}$., long $78^{\circ} 31^{\prime} 27^{\prime \prime W}$.).

Table 1. Wells used in this study.

\begin{tabular}{|c|c|c|c|c|c|c|}
\hline $\begin{array}{l}\text { Regulatory } \\
\text { number }\end{array}$ & API number & Operator & Well name & State & Latitude & Longitude \\
\hline HI-0003 & 4509123504 & $\begin{array}{l}\text { Cabot Oil \& Gas } \\
\text { Corp. }\end{array}$ & $\begin{array}{l}\text { George Washington } \\
\text { National Forest } \\
\text { No. } 1\end{array}$ & Virginia & $38^{\circ} 20^{\prime} 0.24^{\prime \prime}$ & 7944'43.80" \\
\hline HI-0001 & 4509120036 & $\begin{array}{l}\text { Pennzoil United, } \\
\text { Inc. }\end{array}$ & Bertha Smith No. 1 & Virginia & $38^{\circ} 24^{\prime} 50.76^{\prime \prime}$ & 79²0'21.12" \\
\hline RO-0018 & 4516520171 & $\begin{array}{l}\text { Crab Run Gas } \\
\text { Co. }\end{array}$ & $\begin{array}{l}\text { George Washington } \\
\text { National Forest } \\
\text { No. } 3\end{array}$ & Virginia & 38³0'23.40" & 799'16.20" \\
\hline RO-0024 & 4516520384 & $\begin{array}{l}\text { Merrill Natural } \\
\text { Resources, Inc. }\end{array}$ & Floyd Fulk No. 1 & Virginia & 38³9'5.76" & 7859'33.72" \\
\hline RO-0021 & 4516520373 & $\begin{array}{l}\text { Yankee Explora- } \\
\text { tion, Inc. }\end{array}$ & Moyers No. 1 & Virginia & 3848'21.96" & 7856'41.64" \\
\hline HD-0015 & 4703100015 & United Fuel Gas & $\begin{array}{l}\text { William J.B. Orr } \\
\text { No. } 1\end{array}$ & West Virginia & 39¹'31.15" & 78॰49'3.29" \\
\hline PD-0010 & 4707100010 & $\begin{array}{l}\text { Union Drilling } \\
\text { Co. }\end{array}$ & $\begin{array}{l}\text { Monongahela } \\
\text { National Forest } \\
\text { No. } 1\end{array}$ & West Virginia & 3854'36.50" & 79²0'50.82" \\
\hline PD-0011 & 4707100011 & $\begin{array}{l}\text { Berea Oil \& Gas } \\
\text { Corp. }\end{array}$ & $\begin{array}{l}\text { R.C. \& M.M. Hed- } \\
\text { rick No. } 1\end{array}$ & West Virginia & 3850'42.36" & 79³1'28.74" \\
\hline HI-0004 & 4509123522 & $\begin{array}{l}\text { Cabot Oil \& Gas } \\
\text { Corp. }\end{array}$ & $\begin{array}{l}\text { Red Oak Ranch } \\
\quad \text { No. } 1\end{array}$ & Virginia & $38^{\circ} 27^{\prime} 40.68^{\prime \prime}$ & 7940'3.72" \\
\hline
\end{tabular}


Table 2. Apparent thickness of interpreted intervals estimated from wireline logs.

\begin{tabular}{lcccccc}
\hline $\begin{array}{c}\text { Regulatory } \\
\text { number }\end{array}$ & API number & $\begin{array}{c}\text { Millboro Shale } \\
\text { interval 1 } \\
\text { (feet) }\end{array}$ & $\begin{array}{c}\text { Millboro Shale } \\
\text { interval 2 } \\
\text { (feet) }\end{array}$ & $\begin{array}{c}\text { Millboro Shale } \\
\text { interval 3 } \\
\text { (feet) }\end{array}$ & $\begin{array}{c}\text { Millboro Shale } \\
\text { total thickness } \\
\text { (feet) }\end{array}$ & $\begin{array}{c}\text { Needmore Shale } \\
\text { total thickness } \\
\text { (feet) }\end{array}$ \\
\hline HI-0003 & 4509123504 & 99 & 211 & 137 & 447 & 143 \\
HI-0001 & 4509120036 & 96 & 202 & 147 & 445 & 149 \\
RO-0018 & 4516520171 & 64 & 162 & 91 & 317 & 163 \\
RO-0024 & 4516520384 & 141.5 & 294 & 127 & 562.5 & 103 \\
RO-0021 & 4516520373 & 165 & 279 & 76 & 520 & 96.5 \\
HD-0015 & 4703100015 & 58.5 & 231.5 & 177 & 467 & 127 \\
PD-0010 & 4707100010 & 78 & 120 & 53 & 251 & 181.5 \\
PD-0011 & 4707100011 & 108 & 329 & 126.5 & 563.5 & 154.5 \\
HI-0004 & 4509123522 & 103 & 245 & 109.5 & 457.5 & 171.5 \\
& Minimum & 58.5 & 120 & 53 & 251 & 96.5 \\
& Maximum & 165 & 329 & 177 & 563.5 & 181.5 \\
\hline
\end{tabular}

"second-order folds," and folds with wavelengths less than 0.5 mi as "third-order folds." "Disturbed" zones were documented in western Maryland and eastern West Virginia by Jacobeen and Kanes (1974); in central Pennsylvania, western Maryland, and northern West Virginia by Pohn and Purdy (1988); and in northern West Virginia by Schultz (1997). Shumaker (1980) proposed that fractures observed in highly organicrich portions of Devonian shale in oriented cores from wells in Kentucky and West Virginia have a limited stratigraphic extent and are related to stress resulting from their preferential orientation. The cleavage duplexes studied by Nickelsen (1986) showed significant layer-parallel shortening, but no details were given to explain how the shortening affected the thickness measurements of the formation in which the cleavage duplexes occurred. An example of the third-order folding is illustrated in figure 2.

The objective of this study was to test whether the thirdorder folds observed in outcrop were discernible in the subsurface by correlating wireline logs using a computer program not used previously in this tectonic setting. The correlation of nine wireline logs containing gamma-ray and bulk-density curves showed variations in thickness that likely were caused by third-order structural features. Traditional well-log correlation commonly results in the interpretation of absent and repeated sections and selects the location of the fault planes in the subsurface at these interpreted intervals. This study used Correlator 5.2, a computer program originally designed to correlate wireline logs in extensional regimes, such as the U.S. Gulf Coast (Olea, 2002a) and mid-continent regions (Watney and others, 1999; Olea and Guy, 2000; Olea, 2000b). In this study, the program was used for the first time to correlate wireline logs in a contractional tectonic regime. The program was used to infer the locations of discontinuities in the subsurface that may have caused the "disturbed" zones, which were evident in outcrop.

\section{Stratigraphy}

The stratigraphic succession in the study area in eastern West Virginia and western Virginia consists of Cambrian through Lower Mississippian sedimentary rocks, including thick carbonate sequences in the Ordovician, Silurian, and Lower Mississippian and siliciclastic sequences in the Lower and Middle Cambrian, and Devonian. The primary stratigraphic units in this study are the Lower and Middle Devonian mudstone and shale within the Needmore Shale and the Middle Devonian Marcellus Shale and Mahantango Formation. Where the Marcellus Shale and Mahantango Formation cannot be differentiated, they are mapped as one unit and referred to as the Millboro Shale in westernmost Virginia and easternmost West Virginia (de Witt and others, 1993; Rader and Evans, 1993) (fig. 5).

The Needmore Shale overlies the Lower Devonian Oriskany Sandstone in most of the study area where the Lower and Middle Devonian Onondaga Limestone is not present or discernible. The Needmore Shale is a dark-gray, silty shale, typically with subtle to distinct laminations in outcrop. The regionally extensive Middle Devonian Tioga Ash Bed, which consists of brownish-gray to brownish-black, highly micaceous ash and chert, occurs at the top of the Needmore Shale (or the Onondaga Limestone, where the Needmore Shale is absent), separating it from the Marcellus Shale. The Tioga Ash Bed rarely is exposed in the study area because it is highly susceptible to weathering.

The Marcellus Shale in the study area is typically a darkgray to black mudstone or shale with a high organic-material content, weathers to gray or brown chips on outcrop, and contains pyritic zones and zones of calcareous concretions and limestone beds. The Marcellus Shale commonly exhibits welldeveloped jointing in three directions, chaotic bedding, shear zones, pencil fracturing, and fractures that contain calcite and pyrite. 


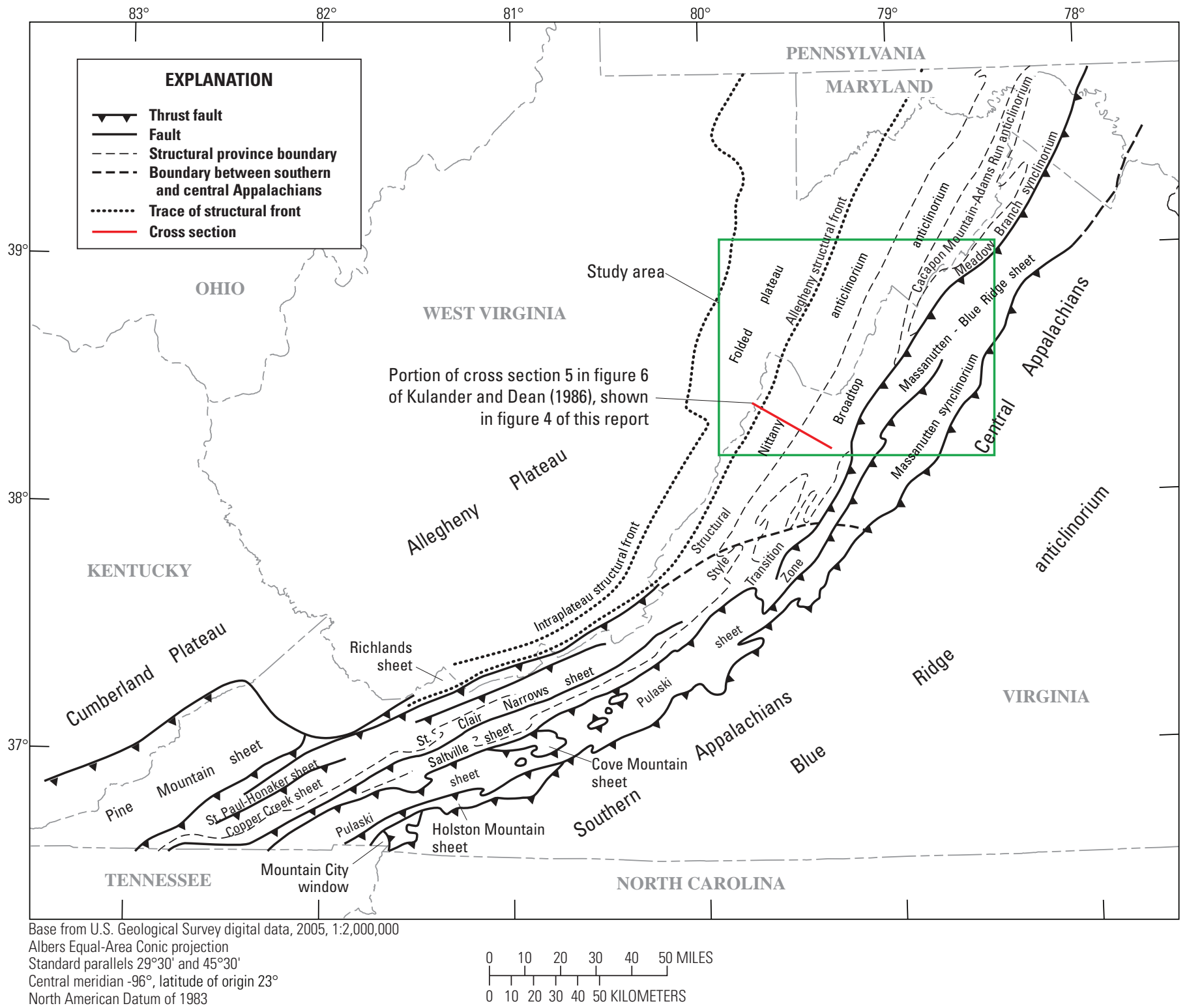

Figure 3. Map showing regional structural geology of eastern West Virginia and western Virginia, including major tectonic features, the location of the cross section shown on figure 4, and the location of the study area shown in figure 7. Modified from Kulander and Dean (1986); used by permission of the American Association of Petroleum Geologists, whose permission is required for further use. 


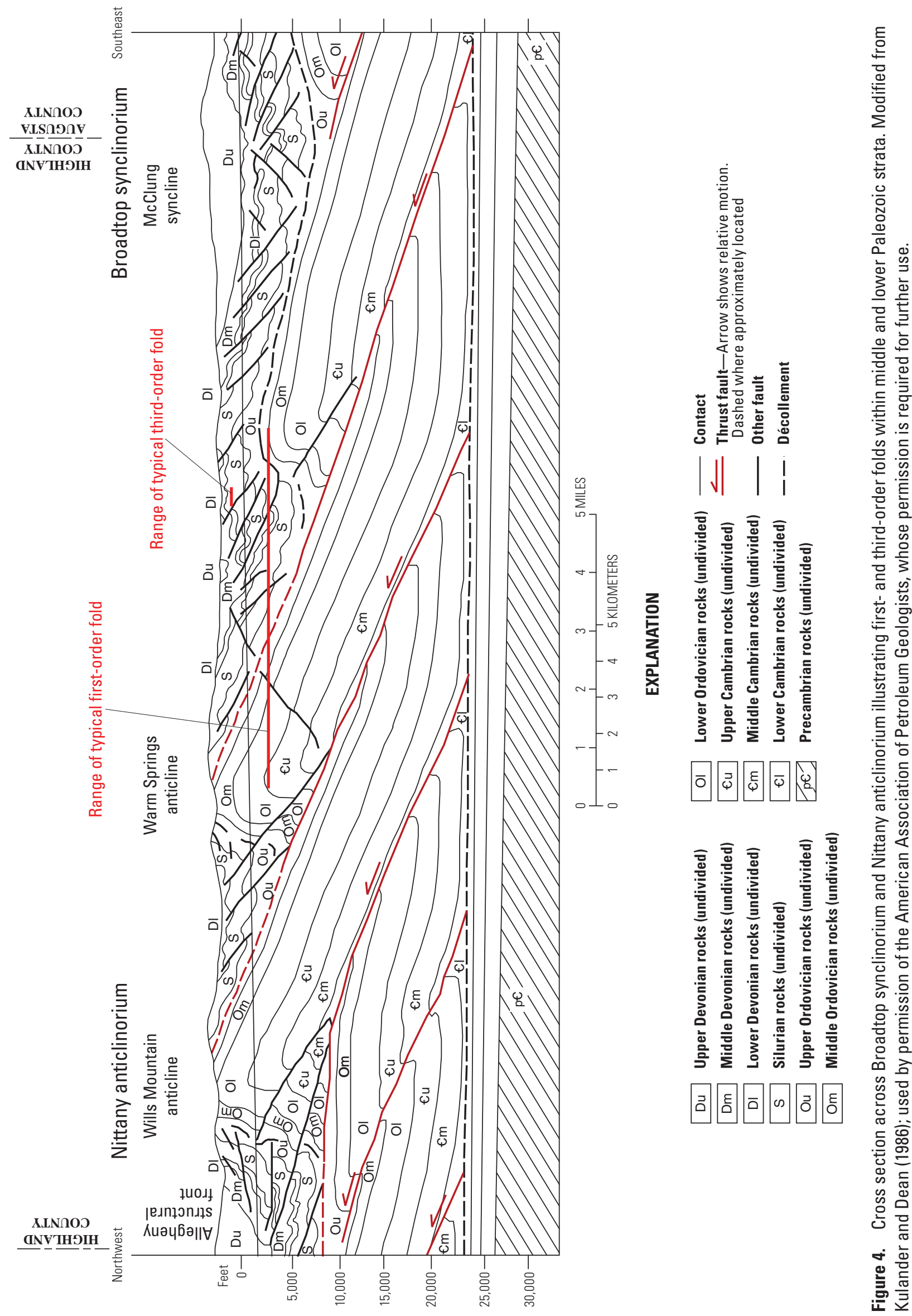




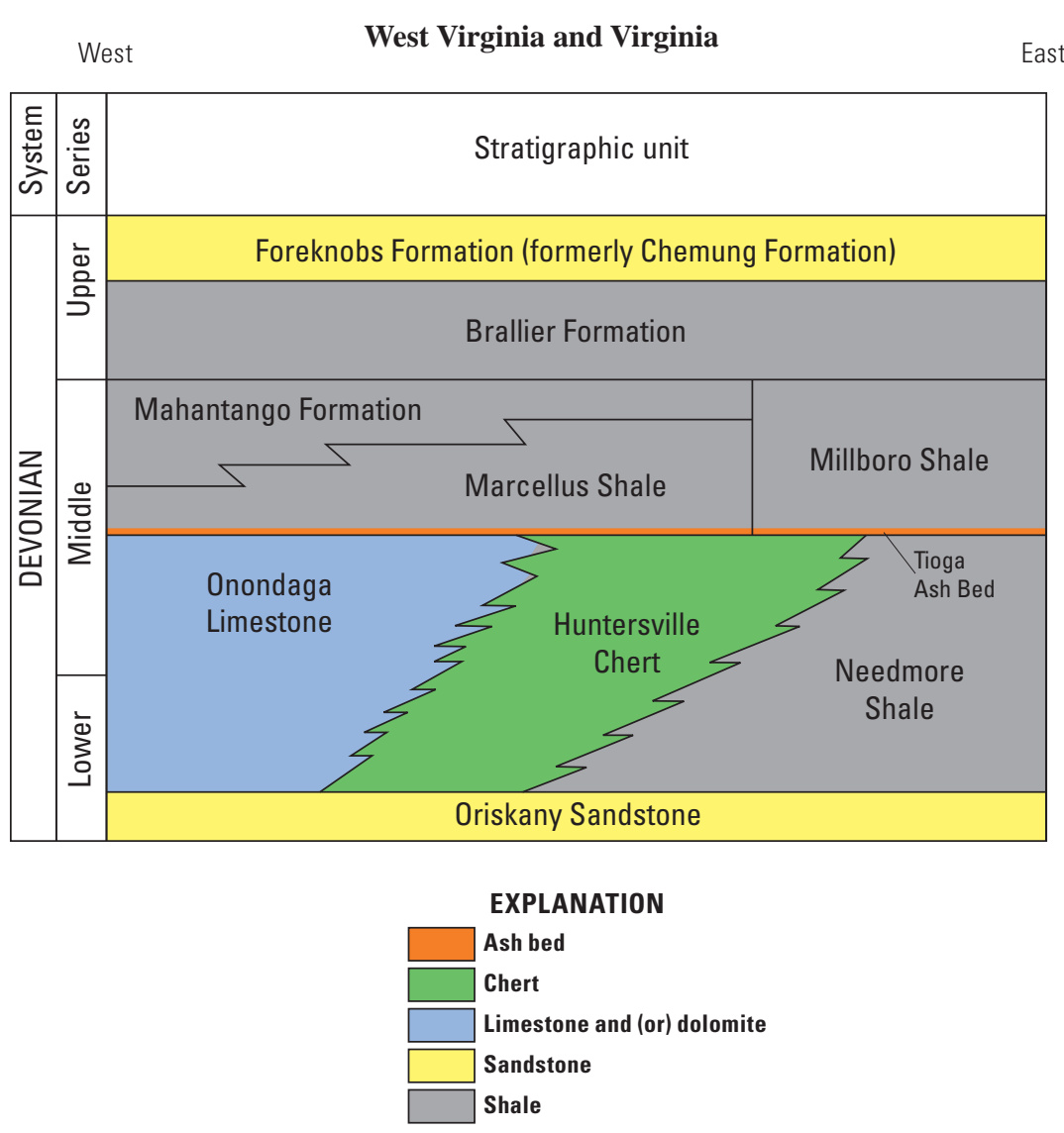

Figure 5. Schematic stratigraphic chart showing Lower Devonian to Upper Devonian strata of the central Valley and Ridge and Appalachian Plateaus provinces in western Virginia and eastern West Virginia. Modified from Kulander and Dean (1986), Flaherty (1996), and Milici and Swezey (2006).

Conformably overlying the Marcellus Shale is the Mahantango Formation, a dark-gray to gray shale and silty shale. The Mahantango Formation typically has low organicmaterial content and minimal chaotic bedding and internal deformation. Concretions are absent to rare. Where the Mahantango Formation cannot be differentiated from the Marcellus Shale, the two formations are mapped collectively as the Millboro Shale in Virginia and West Virginia (de Witt and others, 1993; Rader and Evans, 1993). The Mahantango Formation grades upward into the Upper Devonian Brallier Formation, the base of which is its lowest siltstone bed. The Brallier Formation extends upward to the base of the Upper Devonian Foreknobs Formation, which is a mixed greenishgray and red sandstone and shale interval formerly referred to as the Chemung Formation (Rader and Evans, 1993).

The Marcellus Shale is recognized on gamma-ray wireline logs as one or more highly radioactive zones approximately 100 to $200 \mathrm{ft}$ above the top of the Oriskany Sandstone (Piotrowski and Krajewski, 1977a,b; Schwietering, 1980; Roen and de Witt, 1984; de Witt and others, 1993). These radioactive zones have the highest total organic carbon content and are the objective zones for drilling and production of natural gas in the Marcellus Shale gas play. The distinctive log character of the Marcellus Shale facilitates well-log correlations in the structurally complex Valley and Ridge province. The total thickness of radioactive Marcellus Shale ranges from $0 \mathrm{ft}$ where it pinches out to the west to over $700 \mathrm{ft}$ in southeastern New York (Piotrowski and Harper, 1979; Erenpreiss and others, 2011); however, Smith and others (2009) reported that the thickening that may result from thrust faults may be overlooked easily in typical wireline logs, even though such thrust faults are recognizable in outcrop and high-resolution borehole image logs. Detailed wireline log correlations by Enomoto (2009) suggest that thickness variations within the study area may result from structural deformation in the organic-rich shale intervals. In the study area, the Marcellus Shale and the Mahantango Formation are not differentiated on published geologic maps; therefore, the term "Millboro Shale" was used in the annotation of the formation tops on the wireline well logs and in the accompanying figures.

\section{Structural Geology}

The study area is mostly within the western part of the Valley and Ridge province, including portions of the Broadtop 
synclinorium and the Nittany anticlinorium (figs. 3, 4; Kulander and Dean, 1986); however, the locations of four of the wells used in the study are west of the Allegheny structural front (ASF). In the study area, stratigraphic units at the surface typically range from Lower Devonian to Upper Devonian, with thin intervals of Mississippian strata present in the core of the deepest synclines (Schultz, 1997; Dicken and others, 2005; Nicholson and others, 2005). In some places, Silurian and older Paleozoic rocks reach the surface in the cores of anticlines. The study area is bordered on the northwest by the Appalachian Plateaus province and on the southeast by the North Mountain fault, which brings the lower Paleozoic carbonate strata that floor the Shenandoah Valley into juxtaposition with Devonian strata. According to Jacobeen and Kanes (1974), who used two-dimensional seismic data, sample descriptions of cuttings, and wireline well logs to interpret the subsurface, the thrust faults are rooted in the Ordovician Martinsburg Formation tens of thousands of feet below the surface. This interpretation is used by Kulander and Dean (1986) in their subregional analysis, where they depict regional thrust faults rising out of the Lower Cambrian shale on a structural ramp up into the Ordovician Martinsburg Formation from which the deformation within the Lower and Middle Devonian shale is derived (fig. 4).

Deep, regionally extensive second-order folds associated with the major faults are developed in the lower Paleozoic intervals (Kulander and Dean, 1986; Schultz, 1997) and extend upward into the overlying Devonian strata; the resulting regional anticlines and synclines are manifest in the Devonian strata. A common structural style displayed in outcrops, primarily in the Marcellus Shale, is one of disharmonic folding within the surface and near-surface structures, which produces relatively small folds and local thrust faults. Examples of these smaller, third-order folds are illustrated in Jacobeen and Kanes (1974), Nickelsen (1986), Pohn and Purdy (1988), and Schultz (1997). The variety of vergence directions of the third-order folds suggests that a throughgoing, upper-level décollement zone is not present within the Needmore and Marcellus Shales of the Broadtop synclinorium (Schultz, 1997). Pohn and Purdy (1988) suggested that disharmonic folding and "disturbed" zones are common in incompetent formations, such as the Marcellus Shale, whereas the same stress resulted in wedge faults in competent formations, such as the Oriskany Sandstone.

The study area is located in a structurally complex region near documented lineaments, cross-strike structural discontinuities (CSD) and the ASF. Lineaments are surface features defined by discontinuities or linear features that may be related to subsurface phenomenon (O'Leary and others, 1976) and have an orientation oblique to surrounding features. CSDs are structural features aligned at a high angle to regional strike-parallel patterns, but are defined by surface and subsurface geologic phenomenon (Wheeler, 1980) and thus are better defined and mapped than lineaments. In the study area, the strike of at least three structural features (including the Petersburg CSD) is approximately N. $85^{\circ}$ E., the strike of about six structural features is approximately N. $80^{\circ} \mathrm{W}$., and the strike of at least eight structural features (including the Parsons CSD) is about N. 50 $\mathrm{W}$. (Wheeler, 1980; Wilson, 1980). The strike of the ASF in Highland County, Virginia, is approximately N. $35^{\circ}$ E., which is parallel to the strike of the regional anticlines, synclines, and thrust faults (Rader and Wilkes, 2001). Southworth (1986) concluded that lateral ramps coincided with 32 percent of the lineaments and 70 percent of the cross-strike structural discontinuities that have been studied, suggesting that the lineaments and CSDs may be surface expressions of lateral ramps in the allochthonous cover rocks of the Appalachians. Wilson (1980) noted that splay faults within the Parsons CSD cut the Silurian to Devonian structural lithic unit, transferring the slip along the faults into the Middle Devonian shale, which caused thickening in that sequence. In units where the slip along the fault had been transferred from one detachment horizon to another, such as in the Middle Devonian shale, the unit showed thickening in the hinges of folds and thinning on the limbs of folds (Wilson, 1980). Wilson (1980) also reported that the rocks within the Parsons CSD were more intensely folded with a related increase in joint intensity compared to rocks outside the CSD. Detailed mapping by previous workers also noted a transfer of slip in the Silurian to Devonian sequence along the Petersburg CSD (Wilson, 1980).

Multiple joint sets generated by multiple episodes and directions of stress were described by Dean and others (1983) and Evans (1994) from surface and subsurface data. Crossstrike structural discontinuities were described from surface mapping (Wheeler and others, 1979; Wheeler, 1983) and have been interpreted to extend up to 4 kilometers $(\mathrm{km})$ into the subsurface (Wheeler, 1980; Wilson and Shumaker, 1992). The wells in this study were spaced far enough apart that the features described in these reports may affect the results of this analysis.

\section{Exploration and Production History in the Study Area}

Petroleum exploration in the 1950s and 1960s led to the discovery of several gas fields within the study area (Energy Information Administration (EIA), 2010). In southern Pennsylvania, natural gas was discovered in the Devonian Oriskany Sandstone in the Purcell, Five Forks, and Artemas fields in 1957, 1962, and 1963, respectively. They were abandoned in 1974,1972 , and 1972, respectively, after cumulative production of almost 21 billion cubic feet of (BCF) of gas from the Oriskany Sandstone (Harper and Patchen, 1996).

In Hampshire and Hardy Counties in eastern West Virginia, there is a northeast-southwest-trending line of gas fields that also produced from the Oriskany Sandstone. They include the Creekvale (Gore), Little Cacapon, Augusta, Inkerman, and Lost River fields. The Creekvale (Gore) discovery consisted of two successful wells that were completed, but for which there are no cumulative production data available (Cardwell, 1982). 
The Little Cacapon field, discovered in 1965, produced about $1 \mathrm{BCF}$ of gas. In 1971, the field was converted to a gas storage facility (Cardwell, 1982). The Augusta field produced $1 \mathrm{BCF}$ of gas from 1953 to 1971 before it, too, was converted to a gas storage facility (Cardwell, 1982). The Inkerman (Whip Cove West) field produced 4.8 BCF of gas from 1966 to 1973 and the Lost River (Whip Cove East) field produced 9.1 BCF of gas from 1962 to 1973 (Cardwell and Avary, 1982).

In western Virginia, the Bergton field was discovered in 1935 and lies at the southwestern end of this series of gas fields in the Oriskany Sandstone. Several drilling campaigns took place between 1935 and 1980, when a pipeline was built to a nearby interstate pipeline system to establish commercial production. The last reported production from Rockingham County, where the Bergton field is located, was in 1986. During two periods of production, the field produced slightly over 200 million cubic feet (MMCF) of gas (Milici, 1990).

In Pocahontas County, West Virginia, the Thornwood field was discovered in 1961, and development drilling continued until 1964, but the amount of gas produced from the Oriskany Sandstone during that time is not available (Cardwell and Avary, 1982). In 1996, Cabot Oil recompleted several wells and produced 3.28 BCF of gas through 2010, the last date for which production data are available (WVGES, 2010).

Finally, one of the wells used in this study (PD-0010, table 1) appears to be the southernmost productive gas well in the Jordan Run field in Grant County, West Virginia. Over 41 MMCF of gas has been produced from this well from the Oriskany Sandstone since the PD-0010 well was drilled in 1983. This well has been operated by Chesapeake Energy since 2005.

\section{Procedures}

The wells in this study were chosen in an area approximately $50 \mathrm{mi}$ wide by $50 \mathrm{mi}$ long where published digital geologic maps were available. Nine wells were identified that penetrated as deep as the Oriskany Sandstone and have wireline gamma-ray and bulk-density logs through the Upper to Lower Devonian interval (table 1, plate 1). The regulatory number listed in the first column in table 1 was used as the identifier for each well in the text, figures, and plates of this report. On the basis of the compilation of geologic mapping completed in the study area (Dicken and others, 2005; Nicholson and others, 2005), wells PD-0010, PD-0011, HI-0004, and HI-0003 are located on the western side of the ASF and wells HI-0001, RO-0018, RO-0024, RO-0021, and HD-0015 are located on the eastern side of the ASF. This positional relation led to the assumption that the strata in the wells west of the ASF are likely to be less deformed and have greater petrophysical consistency than the wells east of the ASF. In order to test this assumption, the petrophysical properties measured on the wireline logs were analyzed for evidence of variability that might indicate the presence of third-order folds. Digital images of wireline logs were downloaded from the West Virginia Geological and Economic Survey (2010) and Virginia Division of Gas and Oil (2010) Web sites. The logs were digitized to create $\log$ ASCII $^{1}$ standard (LAS) files that contain gamma-ray and bulk-density curves. Most of the wells had bulk-density curves available, but two logs which had only formation density and density porosity available were converted to bulk-density so that the same log suite and scales could be used for all wells. The LAS files were used as input to the Correlator program.

Drilling reports submitted by the well operators were obtained for the nine wells; these reports included the depths of the tops of formations. Descriptions of drill cuttings were available for four of the nine wells in the study. Using these data as the starting point, IHS Kingdom ${ }^{\mathrm{TM}}$ software was used to facilitate the correlation of the wireline logs. The wireline logs provided gamma-ray (GR) measurements in American Petroleum Institute (API) units, which indicate relative radioactivity. Bulk-density measurements were provided in grams per cubic centimeter (g/cc; also denoted as RHOB (rho B) in oil and gas industry wireline logs, and in the figures and plates in this report). The term "excursion" is used here to indicate the movement of either the gamma-ray or bulk-density curve to the right or left relative to an axis on the log.

The depths to the tops of the Millboro Shale, Needmore Shale, and Oriskany Sandstone in the wireline log for the Fulk No. 1 well (RO-0024; fig. 6) were selected on the basis of traditional pattern recognition. The top of the Oriskany Sandstone was chosen at an excursion of the gamma-ray curve to the left with increasing depth (indicating 50 API units or less) and an excursion of the bulk-density curve to the right with increasing depth (indicating values of $2.65 \mathrm{~g} / \mathrm{cc}$ or higher below the top). These measurements indicated the presence of a clean sandstone with little to no clay content. The top of the Needmore Shale was chosen at the lowest excursion of the gamma-ray curve to the right with decreasing depth (indicating values greater than 160 API units above this depth) and an excursion of the bulk-density curve to the left with decreasing depth (indicating values less than $2.60 \mathrm{~g} / \mathrm{cc}$ ). The top of the Millboro Shale was chosen at the second excursion of the gamma-ray curve to the left, at the top of the second radioactive interval above the Oriskany Sandstone and Needmore Shale (indicating values decreasing to 160 API units or less), and an excursion of the bulk-density curve to the right with decreasing depth (indicating values increasing to $2.60 \mathrm{~g} / \mathrm{cc}$ or greater above this depth).

The tops of the selected formations were entered into the Correlator program on the basis of the above criteria to initiate correlations of the digital wireline logs. In Correlator, two log curves per well were used to compare the amount of shale in a specified interval, and the variability of a second petrophysical property (such as bulk density) was analyzed. The comparisons were done simultaneously using both logs. In this study,

${ }^{1}$ American Standard Code for Information Interchange 


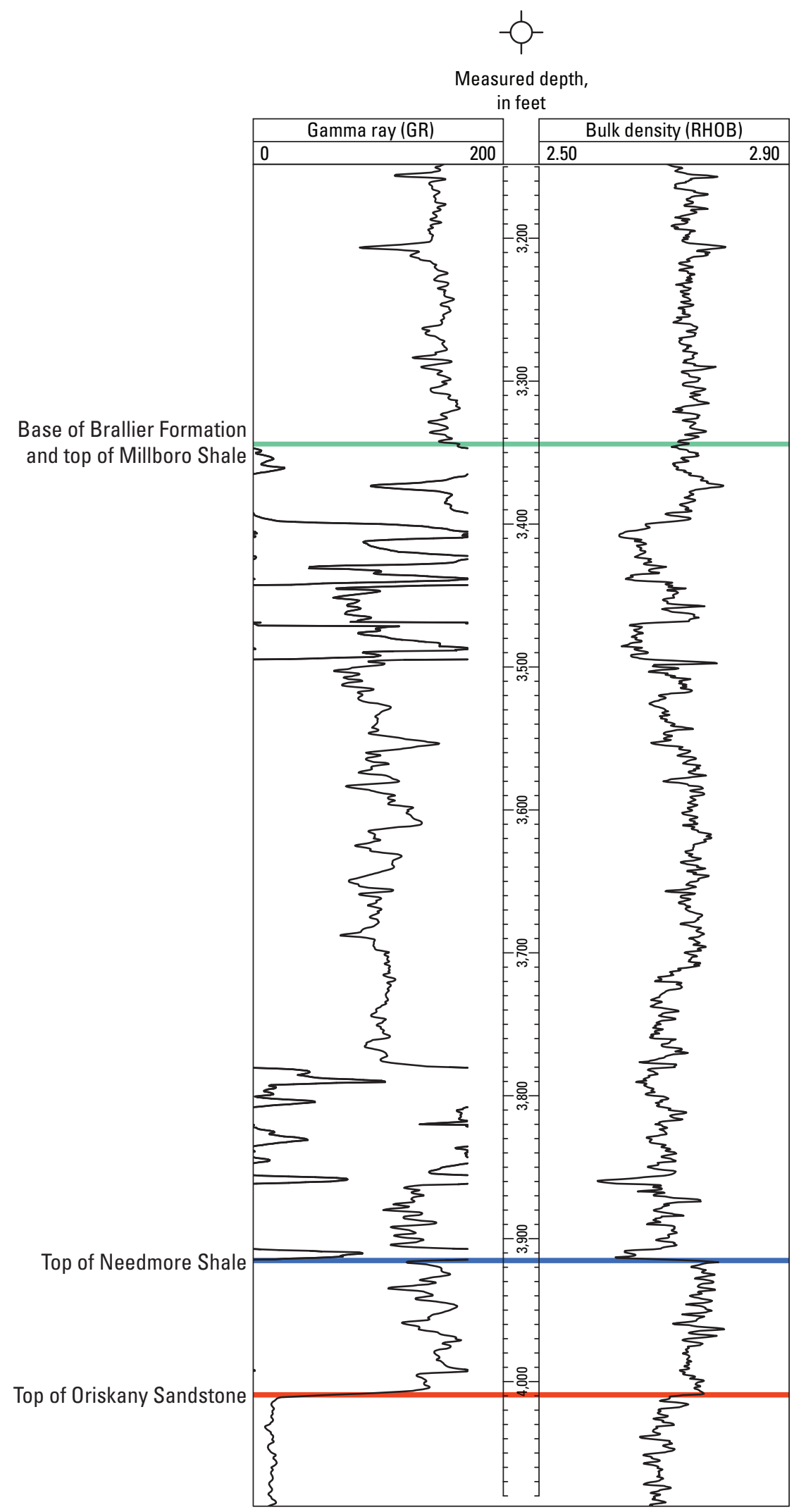

Figure 6. Digital wireline log curves for the Fulk No. 1 well (R0-0024) illustrating the initial interpretation for locating the tops of the Millboro Shale, Needmore Shale, and Oriskany Sandstone using the criteria described in the text. Gamma-ray (GR) intensity measurements, which indicate relative radioactivity, are in American Petroleum Institute (API) units; bulk-density ( $\rho \mathrm{B}$, or RHOB) measurements are in grams per cubic centimeter ( $\mathrm{g} / \mathrm{cc})$. The GR curve wraps on the log scale when API units exceed 200. 
a correlation interval of $15 \mathrm{ft}$ was chosen for the calculations (although the program allows for any interval length to be chosen). The program was implemented in such a way that attention was fixed at a given interval in the well to the left and comparisons were made with multiple possible intervals in the second well on the right. Initially, a few correlations at the maximum variability intervals were obtained using a search interval of $400 \mathrm{ft}$. These first correlations were used to guide the final correlation within a search interval of only $20 \mathrm{ft}$. There was a sequential progression of correlations performed between the top of the Millboro Shale and the top of the Oriskany Sandstone between pairs of wells until logs of all nine wells were correlated. In map view, a line connecting the nine wells in this study formed a closed polygon (fig. 7). The cross sections shown in plates 1 through 4 display the nine wells in the sequence in which they were correlated.

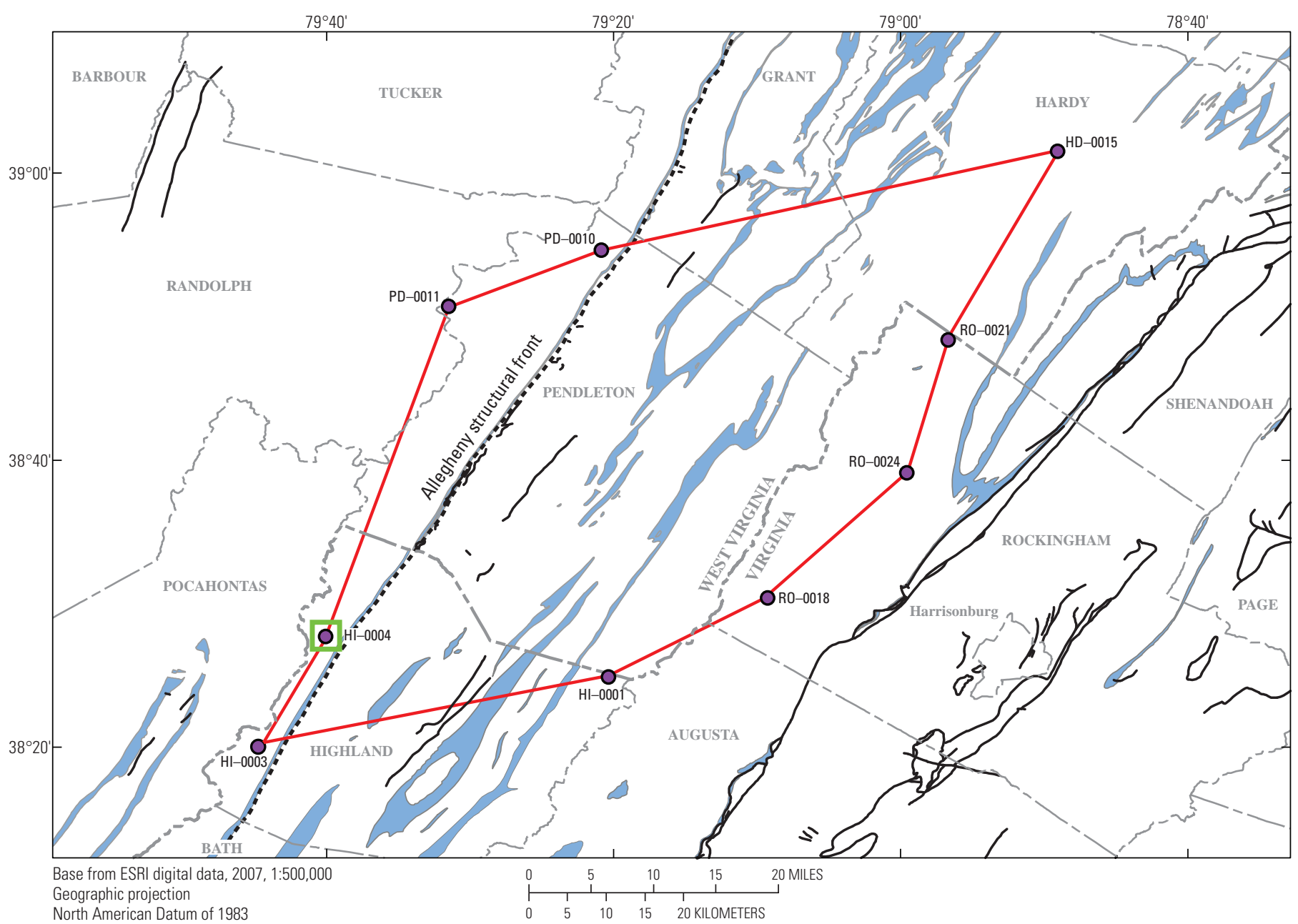

EXPLANATION
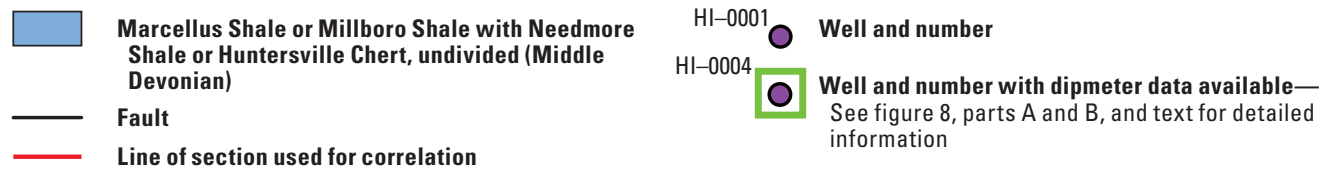

Figure 7. Map of study area showing the outcrop area of the Middle Devonian Marcellus Shale or Millboro Shale with Needmore Shale or Huntersville Chert (undivided), regional faults, and the locations of the nine wells used in this study (including the well with the dipmeter; see figure 8) and the cross sections (see plates 1 through 4). Geology modified from 1:500,000-scale mapping by Dicken and others (2005) and Nicholson and others (2005). 
For the Correlator calculations, depth is denoted in terms of the sequential number of the log readings in the matching well to the right. For example, if the reading for the reference well starts at $850 \mathrm{ft}$ and the sampling interval is $0.5 \mathrm{ft}$, then the sequential number 1 represents a depth of $850 \mathrm{ft}, 2$ represents $850.5 \mathrm{ft}$, and so on; thus, even deeper, the sequential number for $900 \mathrm{ft}$ would be 101. Tracking the depth measurements in the matching log is done relative to the starting point of the reference log. In general,

$$
\text { depth }=d_{0}+\operatorname{spacing} \cdot(i-1)
$$

where

$$
\begin{aligned}
& \text { depth is the depth below a reference datum, such as } \\
& \text { sea level or the kelly bushing; } \\
& d_{0} \quad \text { is the depth of the uppermost wireline log } \\
& \text { reading; } \\
& \text { spacing is the digitization interval; and } \\
& i \text { is the sequential number of log reading }
\end{aligned}
$$

The calculations performed by the Correlator program were as follows (see Olea, 2002b, 2004, for more details):

$$
\alpha_{1,3}(i, k ; n)=1-\frac{1}{2 \cdot n+1} \sum_{j=1-n}^{i+n}\left|\frac{\lambda_{1}(j)-\lambda_{\text {shale } 1}}{\lambda_{\min 1}-\lambda_{\text {shale } 1}}-\frac{\lambda_{3}(j)-\lambda_{\text {shale } 3}}{\lambda_{\min 3}-\lambda_{\text {shale } 3}}\right|
$$

where

$\alpha \quad$ is the coefficient that measures the similarity in shale content; $\alpha$ varies from 0 to 1 , with 1 being the best or an exactly equal amount of shale in the reference and matching wells;

1 used as a subscript, refers to the reference shale log;

3 used as a subscript, refers to the matching shale log;

$i \quad$ is the depth at the center of the correlation interval in the reference well;

$j \quad$ is the depth at the center of the correlation interval in the matching well;

$k \quad$ is the difference between the reference and matching well ( $i$ minus $j$ ); for example, if $i=50$ and $j=150$, then $k=100$.

$n \quad$ is the number of depth measurements to each side of the correlation interval's center;

$\lambda \quad$ is a wireline log reading;

shale is the reading of the shale log; and

$\min$ is the minimum value.

$$
r_{2,4}(i, k ; n)=\frac{\operatorname{cov}_{2,4}(i, k ; n)}{s_{2}(i ; n) \cdot s_{4}(i, k ; n)}
$$

where

$r \quad$ is the correlation coefficient between the other correlation log curves;

2 used as a subscript, refers to the reference log;

4 used as a subscript, refers to the matching log;

$i$ is the depth at the center of the correlation interval in the reference well;

$k \quad$ is the offset for the difference between the reference and matching well; see equation 2) above;

$n \quad$ is the number of depth measurements to each side of the correlation interval's center;

cov is the covariance between depths in the reference and matching wells; and

$s \quad$ is the standard deviation.

The correlation wireline logs are bulk-density logs in this study. The correlation coefficient, $r$, measures the similarity in signature; that is, the ability of one log curve to follow the other log curve. This comparison is scale independent, varies from -1 to 1 , and is calculated by the following:

$$
w_{1,2,3,4}(i, k ; n)=\alpha_{1,3}(i, k ; n) \cdot r_{2,4}(i, k ; n)
$$

where

$w \quad$ is the product of $\alpha$ and $r$, providing a weighted correlation that simultaneously measures the similarity in signature and shale content. Varies from -1 to 1 . Only positive and high correlations are used;

1 refers to the reference shale wireline log;

2 refers to the reference correlation wireline $\log$;

3 refers to the matching shale wireline log;

4 refers to the matching correlation wireline $\log$;

$i \quad$ is the depth at the center of the correlation interval in the reference well;

$k \quad$ is the offset for the difference between the reference and matching well; see equation (2) above;

$n \quad$ is the number of depth measurements to each side of the correlation interval's center.

The Correlator program used the change in absolute measurements on the gamma-ray and bulk-density digital log curves to calculate the weighted correlation coefficient, $w$, between two wells. This process is similar to the way geologists visually correlate wireline logs as they use changes in 
measurements with depth to recognize patterns. The program used the selected correlation interval and search window parameters to determine the best matching correlation, which was defined by the weighted correlation coefficient in equation 4 (plate 2). Only intervals with a weighted correlation coefficient of 0.60 or higher between two wells were displayed and used in further calculations. In the case of the nine study wells, most intervals displayed a correlation strength of 0.60 to 0.68 (blue). No intervals displayed a correlation strength greater than 0.92 (red). The color bar in plate 2 indicates the correlation strength. With the exception of the USGS-standardized index map and explanation, each cross section on plates 1 through 4 is the graphical output from the Correlator program.

\section{Results and Analyses}

The Correlator program calculated the degree of similarity between two logs using specified search parameters. The similarities are discussed below as are some suggested possible reasons for them.

The cross section illustrated in plates 2 through 4 used the top of the Millboro Shale as the datum so that the variation in the thickness of the Millboro Shale would be readily apparent. Another practical consideration was the use of a vertical exaggeration. One vertical scale and another horizontal scale were systematically used in all displays. The log curves of well HI-0003 were chosen arbitrarily to initiate the use of the Correlator program for extending correlations of the tops of the three formations to the other eight wells in the sequential correlation process described above. Because of this choice and the standard operating procedure of the Correlator program, well HI-0003 is displayed at both ends of plates 1 through 4. Because well HI-0003 was compared to a different well at the left side (well HI-0001) of each plate versus the right side (well HI-0004), the results were slightly different and therefore the display looks slightly different at each end of each cross section. During the iterative correlation process, the Millboro Shale was divided into three intervals based on the gamma-ray and bulk-density measurements. The entire Needmore Shale was represented by one undivided interval. From the top of the Millboro Shale to its bottom, the intervals were designated as Millboro Shale interval 1, 2, or 3. These three intervals were identified by color, as shown on plate 3 , if the values exceeded the correlation strength of 0.60 . Millboro Shale intervals 1 and 3 yielded the highest gamma-ray measurements and probably represent the most organic-rich zones of the Millboro Shale. These two intervals were separated by interval 2, which had lower gamma-ray and higher bulkdensity measurements, perhaps representing the calcareous shale and calcareous concretion horizons studied in outcrop. In the final iteration in the nine wells, Millboro Shale interval 1 ranged from 58 to $165 \mathrm{ft}$ thick, Millboro Shale interval 2 ranged from 120 to $329 \mathrm{ft}$ thick, and Millboro Shale interval
3 ranged from 53 to $177 \mathrm{ft}$ thick. The Needmore Shale ranged from 96 to $182 \mathrm{ft}$ thick in the same wells (table 2).

On the basis of the program calculations, intervals that yielded correlation strengths of 60 percent or higher in all nine wells were isolated (plate 4). Four intervals persisted in all nine wells, each with a thickness ranging from 2 to $16 \mathrm{ft}$. These intervals, which exhibited regional continuity, were located near the tops of Millboro Shale interval 2, Millboro Shale interval 3, and the Needmore Shale. A fourth zone that exhibited regional continuity was located within Millboro Shale interval 2.

The measured percentage of each correlated interval that yielded a correlation strength equal to or greater than 60 percent was recorded for each well pair. For each interval, the mean of the percentage was calculated (table 3). The highest mean percentage (71.2 percent) was found in the Needmore Shale, which indicates that this formation had the most consistent wireline-log character in the study area. Within the Millboro Shale, interval 2 yielded a mean percentage of 66.9 percent, which was the highest of all correlated intervals, and therefore indicated that its wireline-log character was the most regionally consistent in the Millboro Shale on the basis of gamma-ray and bulk-density logs. Millboro Shale interval 1 yielded the lowest mean percentage (51.8 percent), which indicated that the wireline-log character of this interval was the least consistent of the four intervals studied. As noted above, the top portion of Millboro Shale interval 1 was not among the four regionally persistent zones in the wells studied.

Mean gamma-ray values (in API units) were calculated for each of the four intervals, and a mean for each interval was calculated for all wells (table 4). Millboro Shale interval 3 yielded the highest mean gamma-ray value for all of the wells (213.0 API units), which was the highest in six of the nine wells. The Needmore Shale and Millboro Shale interval 2 yielded the lowest mean gamma-ray values for all of the wells (147.6 and 127.7 API units, respectively).

Mean bulk-density (RHOB) values (in g/cc) were calculated for each of the four intervals, and a mean for each interval was calculated for all wells (table 5). The Needmore Shale and Millboro Shale interval 2 yielded the highest mean values (2.72 and $2.69 \mathrm{~g} / \mathrm{cc}$, respectively). The gamma-ray and bulk-density values for these two intervals likely reflect their lithologies, suggesting that they contain less clay and perhaps more calcium carbonate or silica. Millboro Shale interval 1 yielded the lowest mean RHOB value for all of the wells ( $2.62 \mathrm{~g} / \mathrm{cc}$ ) and yielded the second highest mean gamma-ray value (191.8 API units). The low mean bulk-density values may indicate a lack of limestone or thin siltstone beds in this interval, and the high mean gamma-ray values may indicate high organic matter content. These properties may have facilitated plastic deformation as a result of stress on this interval. This interval may be the best candidate to exhibit short-wavelength folds and closely spaced thrust faults that may not be observed in more competent formations above and below. 
Table 3. Percentage of the interval where correlation strength between well pairs exceeded 60 percent.

\begin{tabular}{|c|c|c|c|c|c|c|c|c|c|c|}
\hline \multirow{2}{*}{$\begin{array}{c}\text { Stratigraphic } \\
\text { interval }\end{array}$} & \multicolumn{9}{|c|}{ Percentage of interval where correlation strength between well pairs exceeded 60 percent } & \multirow{2}{*}{$\begin{array}{c}\text { Mean } \\
\text { (percent }\end{array}$} \\
\hline & $\begin{array}{l}\text { HI-0003: } \\
\text { HI-0001 }\end{array}$ & $\begin{array}{l}\text { HI-0001: } \\
\text { R0-0018 }\end{array}$ & $\begin{array}{l}\text { RO-0018: } \\
\text { RO-0024 }\end{array}$ & $\begin{array}{l}\text { RO-0024: } \\
\text { RO-0021 }\end{array}$ & $\begin{array}{l}\text { RO-0021: } \\
\text { HD-0015 }\end{array}$ & $\begin{array}{l}\text { HD-0015: } \\
\text { PD-0010 }\end{array}$ & $\begin{array}{l}\text { PD-0010: } \\
\text { PD-0011 }\end{array}$ & $\begin{array}{l}\text { PD-0011: } \\
\text { HI-0004 }\end{array}$ & $\begin{array}{l}\text { HI-0004: } \\
\text { HI-0003 }\end{array}$ & \\
\hline $\begin{array}{l}\text { Millboro Shale } \\
\text { interval } 1\end{array}$ & 84.8 & 31.9 & 46 & 55.5 & 47.2 & 47.5 & 14.6 & 82.9 & 55.8 & 51.8 \\
\hline $\begin{array}{c}\text { Millboro Shale } \\
\text { interval } 2\end{array}$ & 74.9 & 79.6 & 79.9 & 86.3 & 63.7 & 34.6 & 56.7 & 56.2 & 69.9 & 66.9 \\
\hline $\begin{array}{c}\text { Millboro Shale } \\
\text { interval } 3\end{array}$ & 81.3 & 51.4 & 55.5 & 62.6 & 60.9 & 0 & 53.7 & 63.5 & 65.2 & 54.9 \\
\hline Needmore Shale & 87.2 & 77.5 & 29.9 & 54.5 & 72.5 & 82.7 & 67.7 & 98.4 & 70.4 & 71.2 \\
\hline
\end{tabular}

Table 4. Mean gamma-ray values, calculated for each interval.

[API, American Petroleum Institute]

\begin{tabular}{|c|c|c|c|c|c|c|c|c|c|c|}
\hline \multirow{2}{*}{$\begin{array}{l}\text { Stratigraphic } \\
\text { interval }\end{array}$} & \multicolumn{9}{|c|}{ Mean gamma-ray intensity (API units) for each interval } & \multirow{2}{*}{$\begin{array}{c}\text { Mean } \\
\text { (API units) }\end{array}$} \\
\hline & HI-0003 & HI-0001 & RO-0018 & RO-0024 & RO-0021 & HD-0015 & PD-0010 & PD-0011 & HI-0004 & \\
\hline $\begin{array}{l}\text { Millboro Shale } \\
\text { interval } 1\end{array}$ & 151.8 & 259.3 & 184.3 & 234.3 & 204.1 & 120.9 & 201.6 & 184.7 & 185.0 & 191.8 \\
\hline $\begin{array}{c}\text { Millboro Shale } \\
\text { interval } 2\end{array}$ & 127.1 & 106.6 & 99.8 & 126.3 & 138.6 & 96.2 & 123.1 & 180.6 & 151.2 & 127.7 \\
\hline $\begin{array}{c}\text { Millboro Shale } \\
\text { interval } 3\end{array}$ & 198.9 & 230.3 & 162.9 & 193.0 & 268.4 & 146.2 & 263.7 & 244.3 & 209.6 & 213.0 \\
\hline $\begin{array}{l}\text { Needmore } \\
\text { Shale }\end{array}$ & 126.9 & 159.1 & 115.7 & 175.0 & 186.2 & 107.1 & 153.4 & 154.9 & 149.9 & 147.6 \\
\hline
\end{tabular}

Table 5. Mean bulk-density values calculated for each interval.

[g/cc, grams per cubic centimeter]

\begin{tabular}{|c|c|c|c|c|c|c|c|c|c|c|}
\hline \multirow{2}{*}{$\begin{array}{c}\text { Stratigraphic } \\
\text { interval }\end{array}$} & \multicolumn{9}{|c|}{ Mean bulk density (g/cc) calculated for each interval } & \multirow{2}{*}{$\begin{array}{l}\text { Mean } \\
\text { (g/cc) }\end{array}$} \\
\hline & HI-0003 & HI-0001 & RO-0018 & RO-0024 & RO-0021 & HD-0015 & PD-0010 & PD-0011 & HI-0004 & \\
\hline $\begin{array}{l}\text { Millboro Shale } \\
\text { interval } 1\end{array}$ & 2.61 & 2.55 & 2.52 & 2.67 & 2.71 & 2.61 & 2.66 & 2.61 & 2.61 & 2.62 \\
\hline $\begin{array}{c}\text { Millboro Shale } \\
\text { interval } 2\end{array}$ & 2.72 & 2.63 & 2.58 & 2.70 & 2.72 & 2.85 & 2.68 & 2.66 & 2.70 & 2.69 \\
\hline $\begin{array}{c}\text { Millboro Shale } \\
\text { interval } 3\end{array}$ & 2.62 & 2.57 & 2.58 & 2.66 & 2.63 & 2.81 & 2.58 & 2.56 & 2.63 & 2.63 \\
\hline $\begin{array}{l}\text { Needmore } \\
\text { Shale }\end{array}$ & 2.68 & 2.71 & 2.68 & 2.72 & 2.72 & 2.88 & 2.71 & 2.64 & 2.71 & 2.72 \\
\hline
\end{tabular}


Millboro Shale interval 3 yielded the second lowest mean percentage of correlated intervals for all of the wells (54.9 percent) and the second lowest mean bulk-density value for all of the wells ( $2.63 \mathrm{~g} / \mathrm{cc})$. The low mean bulk-density values may indicate a lack of limestone or thin siltstone beds in this interval, and the high mean gamma-ray values may indicate high organic matter content. As with Millboro Shale interval 1, these properties may have facilitated plastic deformation as a result of stress on this interval.

On the basis of the data on mean gamma-ray and bulkdensity values, there seems to be an association between low percentages of correlated intervals and ductile lithologies. Millboro Shale intervals 1 and 3 yielded the lowest mean percentage of correlated interval, may contain the most clayor organic-rich material, and therefore may have been most affected by third-order folding and (or) faulting.

Well HI-0004 is located west of the ASF and was the only well of the nine studied with a dipmeter log available (fig. 8A,B). The log takes the form of a "tadpole" plot where solid tadpoles indicate sufficient correlation of the acquired resistivity data to determine an attitude of the beds, and hollow tadpoles indicate minimal correlation of the acquired resistivity data. Between 6,125 and 6,210 ft measured depth (MD) in this well, in an interval above the Millboro Shale described as dark-gray, platy, slightly calcareous shale on the mud log, the tadpole plot indicated $2^{\circ}$ to $5^{\circ}$ of dip to the north, northwest, east, and southeast; this interval is marked as ' $a$ ' in figure $8 A$. Within Millboro Shale interval 1 , from 6,260 to $6,300 \mathrm{ft} \mathrm{MD}$, the dip was about $2^{\circ}$ to the east and southeast ( $b$ in figure $8 A$ ). From 6,300 to 6,344 ft MD, still within Millboro Shale interval 1, most of the tadpoles were hollow ( $c$ in figure $8 A$ ). and the dip magnitude varied from $2^{\circ}$ to greater than $60^{\circ}$ to the west, northeast, and southeast. Within Millboro Shale interval 2, from 6,354 to 6,452 ft MD, the dips ranged from $2^{\circ}$ to $22^{\circ}$ to the southeast, southwest, northwest, and west ( $d$ in figure $8 A$ ). Between 6,456 ft and $6,580 \mathrm{ft} \mathrm{MD}$, the solid tadpoles indicated dips from $5^{\circ}$ to $50^{\circ}$ to the southwest, southeast, east, northeast, and northwest ( $e$ in figure $8 A, B$ ). Rarely were there two solid tadpoles within a 4-ft interval indicating the same magnitude or direction of dip. Lastly, within Millboro Shale interval 3, the dip directions and magnitudes were extremely variable between 6,590 and 6,682 $\mathrm{ft} \mathrm{MD}$, with the few solid tadpoles indicating dips to the east and southeast with magnitudes between $16^{\circ}$ and $54^{\circ}$ and hollow tadpoles indicating dips up to $75^{\circ}$ to the southwest, west, northwest, northeast, and east ( $f$ in figure $8 B$ ). Near the base of Millboro Shale interval 3, between 6,684 and $6,700 \mathrm{ft} \mathrm{MD}$, the dip varied between $10^{\circ}$ and $22^{\circ}$ to the southeast ( $g$ in figure $8 B$ ). Within the Needmore Shale, from 6,700 to 6,812 $\mathrm{ft} \mathrm{MD}$, the concentration of solid tadpoles was high and the dips varied from $8^{\circ}$ to $28^{\circ}$, mostly to the southeast ( $h$ in figure $8 B$ ). The consistent dip direction exhibited on the dipmeter in well HI-0004 within the Needmore Shale and in portions of Millboro Shale interval 2 seems to indicate that these intervals were more competent and less likely to exhibit plastic deformation as a result of tectonic stress compared to Millboro Shale intervals 1 and 3. The variable dip magnitude and direction throughout the Millboro Shale intervals 1 and 3 may be explained by intraformational folding, shearing, and (or) faulting.

Millboro Shale interval 1 yielded only a 14.6 percent correlation value between wells PD-0010 and PD-0011 (table 3). Well PD-0010 contained the thinnest Millboro Shale interval 3 and thinnest total Millboro Shale, whereas well PD-0011 contained the thickest Millboro Shale interval 2 and thickest total Millboro Shale (table 2). Conversely, well PD-0010 contained the thickest Needmore Shale of the nine wells (table 2). Wells PD-0010 and PD-0011 were among the most closely spaced pairs, but well PD-0010 is located between the traces of the Mathias lineament (Pohn, 2000) and the Parsons lineament (Southworth, 1986). According to Pohn (2000), the identifying characteristics of the Mathias lineament (a lateral ramp) include an abrupt change in fold wavelengths, a change in fault frequency at the surface, and an abrupt change in facies thickness. Among other characteristics, the high frequency of "disturbed” zones north of the Mathias lineament and documented by field investigations (Pohn, 2000) may explain why well PD-0010 yielded some of the lowest correlation interval values between it and adjacent wells for all three Millboro Shale intervals.

A correlation of 34.6 percent of the interval between wireline logs of wells PD-0010 and HD-0015 was the lowest of all well pairs in Millboro Shale interval 2 and was 0 in Millboro Shale interval 3 (table 3, plates 2, 3). These wells are on opposite sides of the ASF and are on opposite sides of the Mathias lineament; well HD-0015 lies near the interpreted position of the Petersburg lineament (Southworth, 1986), and well PD-0010 is located near the trace of the Mathias lineament as well as the ASF. The lineaments and lateral ramps described by Pohn (2000) are the result of contractional tectonic stress; therefore, it is likely that these major structural features caused discontinuities within the relatively incompetent Millboro Shale.

The correlation of over 80 percent between wells HI-0003 and HI-0001 was among the highest for Millboro Shale intervals 1 and 3 and for the Needmore Shale; in Millboro Shale interval 2, the correlation between the same wells was 74.9 percent (table 3). The Correlator program determined similar weighted correlation coefficients $(w)$, which indicated a similarity in shale content and bulk-density signature in the specified search windows between the well pairs. Because these wells are on opposite sides of the ASF and there is significant distance between them, the results were surprising. Therefore, regardless of the distance between wells HI-0003 and HI-0001 and their apparent relationship to the ASF, the petrophysical properties in the studied intervals in each well were determined to be similar. 
$\boldsymbol{A}$

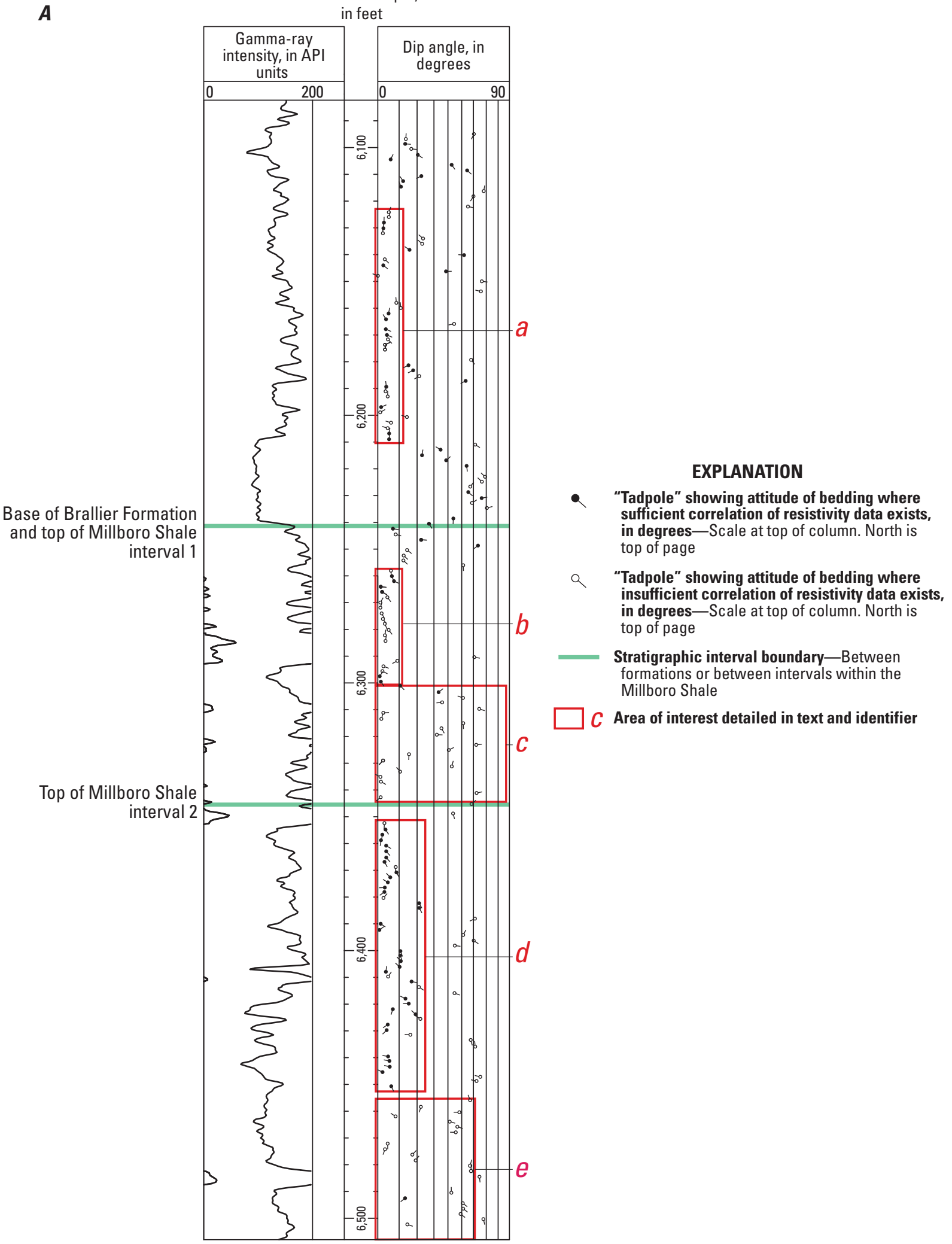

Figure 8. Wireline log showing gamma-ray and dipmeter measurements in well HI-0004, Highland County, Virginia. The "tadpoles" in the rightmost column point in the direction of dip, with north at the top of the log. Tadpoles are located on a scale of $0^{\circ}$ to $90^{\circ}$ to illustrate dip magnitude. $A$, from 6,100 to 6,490 feet. $B$, from 6,490 feet to 6,880 feet. 
$\boldsymbol{B}$

Measured depth,

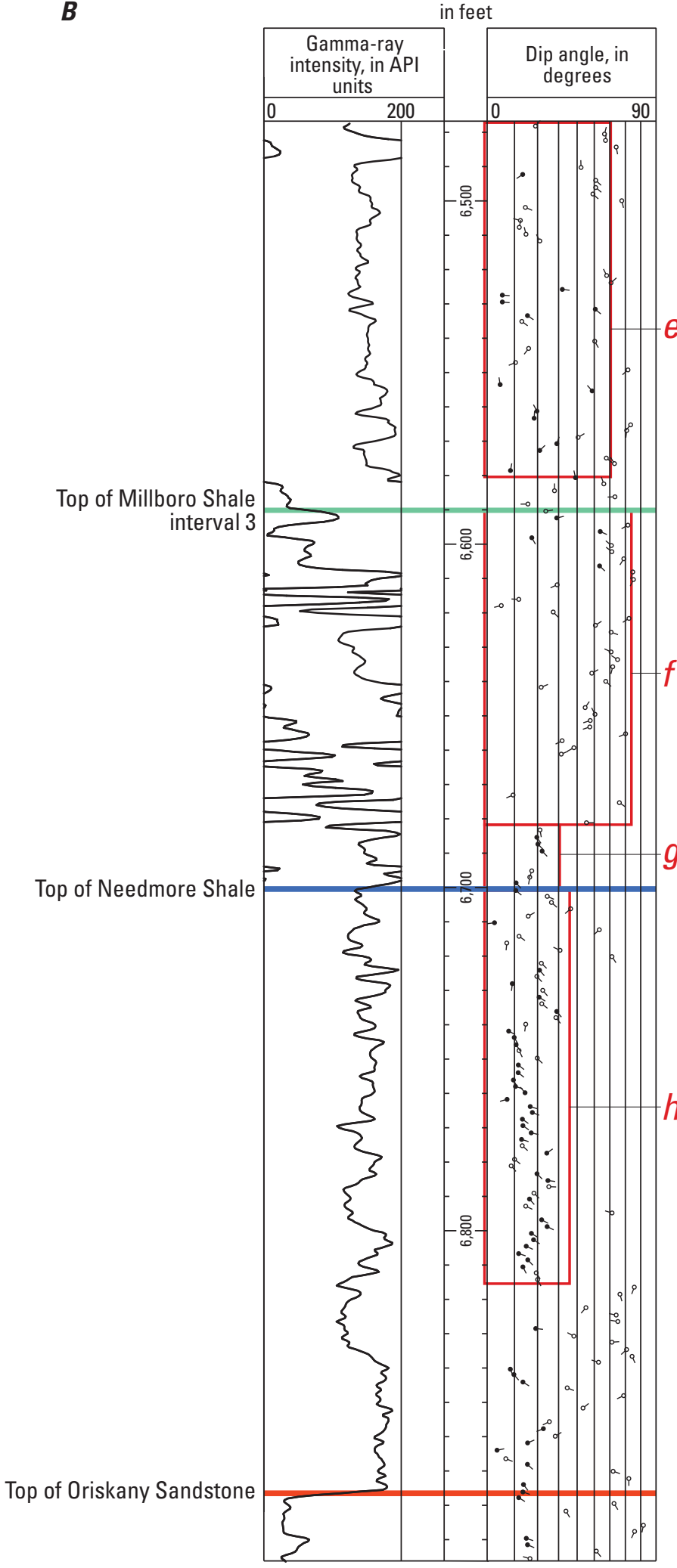

\section{EXPLANATION}

- "Tadpole" showing attitude of bedding where sufficient correlation of resistivity data exists, in degrees-Scale at top of column. North is top of page

a "Tadpole" showing attitude of bedding where insufficient correlation of resistivity data exists, in degrees-Scale at top of column. North is top of page

- Stratigraphic interval boundary-Between formations or between intervals within the Millboro Shale

$g$ Area of interest detailed in text and identifier

Figure 8. Wireline log showing gamma-ray and dipmeter measurements in well HI-0004, Highland County, Virginia. The "tadpoles" in the rightmost column point in the direction of dip, with north at the top of the log. Tadpoles are located on a scale of $0^{\circ}$ to $90^{\circ}$ to illustrate dip magnitude. $A$, from 6,100 to 6,490 feet. $B$, from 6,490 feet to 6,880 feet.-Continued 


\section{Conclusions}

A statistical correlation of strata in the Millboro Shale and Needmore Shale was achieved using the Correlator program, which suggests that it can be a useful correlation tool in regions of contractional deformation. The results of the objective correlation performed by Correlator and illustrated by the "persistent correlations" shown on plate 4 are very similar to the correlations created by a visual inspection of the wireline logs before using the program. The results indicate that the petrophysical properties (primarily mineralogy and porosity) measured by gamma-ray and bulk-density (RHOB) logs are fairly consistent across the study area.

Although the Millboro Shale generally exhibited consistent petrophysical properties, the results of performing a statistical correlation between wireline logs from these nine wells indicated that there are discontinuities within the Millboro Shale where there are significant thickness differences between wells. The measured difference in the correlation strength of Millboro Shale interval 2 between wells compared with that of Millboro Shale intervals 1 and 3 suggests that intervals 1 and 3 may contain more third-order folds and sheared or "disturbed" zones than interval 2. Millboro Shale intervals 1 and 3 likely contain mineralogy that make these zones more prone to layer-shortening cleavage duplexes and (or) disharmonic folding than Millboro Shale interval 2 and the Needmore Shale; however, the discontinuities, which were indicated by variations in the mathematical correlation strength, were not specific enough to locate these zones in the wells that contain third-order folds or duplexes.

\section{Acknowledgments}

Reviews by David Houseknecht and Robert Milici of the U.S. Geological Survey improved the manuscript. The well-location data and log raster files were acquired from the Virginia Division of Gas and Oil and the West Virginia Geological and Economic Survey. The authors thank Patrick Niemeyer, who digitized the log raster files and created the LAS files that were used in this study.

\section{References Cited}

Boyce, M.L., and Carr, T.R., 2009, Lithostratigraphy and petrophysics of the Devonian Marcellus interval in West Virginia and southwestern Pennsylvania, in Carr, Tim, D'Agostino, Tony, Ambrose, William, Pashin, Jack, and Rosen, N.C., eds., Unconventional energy resources; Making the unconventional conventional; Proceedings, 29th Annual Gulf Coast Section SEPM Foundation Bob F. Perkins Research Conference, Houston, Tex., December 6-8, 2009: Houston, Tex., Gulf Coast Section of Society for Sedimentary Geology (SEPM), p. 254-281.

Cardwell, D.H., 1982, Oriskany and Huntersville gas fields of West Virginia (and deep well and structural geologic map): West Virginia Geological and Economic Survey Mineral Resources Series MRS-5A, 180 p., 2 pls., scale 1:250,000.

Cardwell, D.H., and Avary, K.L., 1982, Oil and gas fields of West Virginia: West Virginia Geological and Economic Survey Mineral Resources Series MRS-7B, 171 p., 2 pls., scale 1:250,000.

Coleman, J.L., Milici, R.C., Cook, T.A., Charpentier, R.R., Kirschbaum, Mark, Klett, T.R., Pollastro, R.M., and Schenk, C.J., 2011, Assessment of undiscovered oil and gas resources of the Devonian Marcellus Shale of the Appalachian Basin Province, 2011: U.S. Geological Survey Fact Sheet 2011-3092, 2 p., http://pubs.usgs.gov/fs/2011/3092/.

Dean, S.L., Baranoski, M., Bertoli, L., Kribbs, G., Stephens, T., Kulander, B., Lockman, D., and Mumpower, D., 1983, Regional fracture analysis in western Valley and Ridge and adjoining plateau, West Virginia and Maryland [abs.]: American Association of Petroleum Geologists Bulletin, v. 67, no. 3, p. 448, http://archives.datapages.com/data/ bulletns/1982-83/data/pg/0067/0003/0400/0448.htm.

Dean, S.L., Kulander, B.R., and Lessing, P., 1985, Geology of the Capon Springs, Mountain Falls, Wardensville, Woodstock, and Yellow Spring quadrangles, Hampshire and Hardy Counties, West Virginia: West Virginia Geological and Economic Survey Map-WV26, 1 sheet, scale 1:24,000.

de Witt, Wallace, Jr., Roen, J.B., and Wallace, L.G., 1993, Stratigraphy of Devonian black shales and associated rocks in the Appalachian Basin, in Roen, J.B., and Kepferle, R.C. eds., Petroleum geology of the Devonian and Mississippian black shale of eastern North America: U.S. Geological Survey Bulletin 1909, p. B1-B57, http://pubs.er.usgs.gov/ publication/b1909. 
Dicken, C.L., Nicholson, S.W., Horton, J.D., Kinney, S.A., Gunther, Gregory, Foose, M.P., and Mueller, J.A.L., 2005, Preliminary integrated geologic map databases for the United States; Delaware, Maryland, New York, Pennsylvania, and Virginia: U.S. Geological Survey Open-File Report 2005-1325, 45 p., database, http://pubs.usgs.gov/ of $/ 2005 / 1325 /$.

Energy Information Agency, 2010, Shapefile for the Appalachian Basin, in Natural gas; Maps; Exploration, resources, reserves, and production: Energy Information Agency Web page accessed March 29, 2013 at http://www.eia.doe.gov/ pub/oil_gas/natural_gas/analysis_publications/maps/ maps.htm.

Enomoto, C.B., 2009, Hydrocarbon potential of the Devonian Millboro (Marcellus) Shale in the Valley and Ridge Province of Virginia [abs.], in Abstracts, AAPG Eastern Section Meeting, Evansville, Indiana, September 20-22, 2009: Tulsa, Okla., American Association of Petroleum Geologists, p. 36-37, http://www.searchanddiscovery.net/ abstracts/html/2009/eastern/abstracts/enomoto.htm.

Erenpreiss, M.S., Wickstrom, L.H., Perry, C.J., Riley, R.A., Martin, D.R., and others, 2011, Organic thickness map of the "Marcellus" modified from Harper and Kostelnik (2011), Pennsylvania Geological Survey; Kristin Carter (2008), Pennsylvania MRCSP; James Leone, New York; and Eric Lewis (2011), West Virginia: Pennsylvania Department of Conservation and Natural Resources Web page accessed May 16, 2013, at http://www.dcnr.state.pa.us/cs/ groups/public/documents/document/dcnr_007597.pdf.

Evans, M.A., 1994, Joints and décollement zones in Middle Devonian shales; Evidence for multiple deformation events in the central Appalachian Plateau: Geological Society of America Bulletin, v. 106, no. 4, p. 447-460, doi:10.1130/0016-7606(1994)106<0447:JADCZI> 2.3.CO;2.

Flaherty, K.J., 1996, Play Dho; Fractured Middle Devonian Huntersville Chert and Lower Devonian Oriskany Sandstone, in Roen, J.B., and Walker, B.J., eds., 1996, The atlas of major Appalachian gas plays: West Virginia Geological and Economic Survey Publication V-25, p. 103-108.

Harper, J.A., and Patchen, D.G., 1996, Play Dos: Lower Devonian Oriskany sandstone structural play, in Roen, J.B., and B.J., Walker, eds., The atlas of major Appalachian gas plays: West Virginia Geological and Economic Survey Publication V-25, p. 109-117.

Harris, L.D., and Milici, R.C., 1977, Characteristics of thin-skinned style of deformation in the southern Appalachians, and potential hydrocarbon traps: U.S. Geological Survey Professional Paper 1018, 45 p. (Also available at http://pubs.er.usgs.gov/publication/pp1018.)
Hasson, K.O., and Dennison, J.M., 1988, Devonian shale lithostratigraphy, central Appalachians, U.S.A., in McMillan, N.J., Embry, A.F., and Glass, D.J., eds., Devonian of the World: Proceedings of the Second International Symposium on the Devonian System, Calgary, Canada; v. II; Sedimentation: Canadian Society of Petroleum Geologists Memoir 14, p. $157-177$.

Jacobeen, Frank, Jr., and Kanes, W.H., 1974, Structure of Broadtop synclinorium and its implications for Appalachian structural style: American Association of Petroleum Geologists Bulletin, v. 58, no. 3, p. 362-375. (Also available at http://archives.datapages.com/data/bulletns/1974-76/data/ pg/0058/0003/0350/0362.htm.)

Kulander, B.R., and Dean, S.L., 1986, Structure and tectonics of central and southern Appalachian Valley and Ridge and Plateau Provinces, West Virginia and Virginia: American Association of Petroleum Geologists Bulletin v. 70, no. 11, p. 1674-1684. (Also available at http://archives.datapages. com/data/bulletns/1986-87/data/pg/0070/0011/1650/ 1674.htm.)

Milici, R.C., 1990, Oil and gas exploration and development in Virginia, 1979-1988: Virginia Minerals, v. 36, no. 1, p. $1-6$.

Milici, R.C. and Swezey, C.S., 2006, Assessment of Appalachian Basin oil and gas resources; Devonian Shale-Middle and Upper Paleozoic Total Petroleum System: U.S. Geological Survey Open-File Report 2006-1237, 70 p., available only at http://pubs.usgs.gov/of/2006/1237/.

Nicholson, S.W., Dicken, C.L., Horton, J.D., Labay, K.A., Foose, M.P., and Mueller, J.A.L., 2005, Preliminary integrated geologic map databases for the United States; Kentucky, Ohio, Tennessee, and West Virginia: U.S. Geological Survey Open-File Report 2005-1324, available only at http://pubs.usgs.gov/of/2005/1324/.

Nickelsen, R.P., 1963, Fold patterns and continuous deformation mechanisms of the central Pennsylvania folded Appalachians, in Wagner, W.R., and Nickelsen, R.P., eds., Tectonics and Cambrian-Ordovician stratigraphy, central Appalachians of Pennsylvania, Guidebook, Pittsburgh Geological Society and Appalachian Geological Society field trip, September 19-21, 1963: Pittsburgh, Pa., Pittsburgh Geological Society, p. 13-29. (Also available at http:// archives.datapages.com/data/appalachian/tectonics_camb_ ordostrat63/nickelsen.pdf.)

Nickelsen, R.P., 1986, Cleavage duplexes in the Marcellus Shale of the Appalachian foreland: Journal of Structural Geology, v. 8, no. 3/4, p. 361-371, doi:10.1016/01918141(86)90055-6. 
Ohio Department of Natural Resources, 2010, Stratigraphic cross section trending northwest-southeast (along dip) illustrating the Devonian Shale interval in eastern Ohio and west-central West Virginia: Columbus, Ohio, Ohio Department of Natural Resources, Division of Geological Survey, Web page accessed March 29, 2013, at http://ohiodnr.com/ OhioGeologicalSurvey/tabid/23014/Default.aspx.

Olea, R.A., 2002a, Correlator, an interactive computer program for high-resolution, lithostratigraphic, well-log correlation: Kansas Geological Survey Open-File Report 2002-51, http://www.kgs.ku.edu/Publications/OFR/2002/ OFR02_51/ManualOFR2002-51.pdf.

Olea, R.A., 2002b, CORRELATOR cross section from Gove to Harper Counties, Kansas: Kansas Geological Survey Technical Series 16, 2 pls.

Olea, R.A., 2004, Correlator 5.2 - a program for interactive lithostratigraphic correlation of wireline logs: Computers \& Geosciences, v. 30, p. 561-567, doi:10.1016/j. cageo.2004.01.006.

Olea, R.A., and Guy, W.J., 2000, Subsurface geology of the Schaben field, Ness County, Kansas: Kansas Geological Survey Open-File Report 2000-52, 10 p., http://www.kgs. ku.edu/PRS/publication/2000/ofr52/index.html.

O’Leary, D.W., Friedman, J.D., and Pohn, H.A., 1976, Lineaments, linear, lineation; Some proposed new standards for old terms: Geological Society of America Bulletin, v. 87, no. 10, p. 1463-1469, doi:10.1130/00167606(1976)87<1463:LLLSPN>2.0.CO;2.

Piotrowski, R.G., and Harper, J.A., 1979, Black shale and sandstone facies of the Devonian "Catskill" clastic wedge in the subsurface of western Pennsylvania: U.S. Department of Energy Morgantown Energy Technology Center, Eastern Gas Shales Project Series. 13, 40 p., 39 pls. (Also available at http://www.dcnr.state.pa.us/topogeo/econresource/oilandgas/marcellus/marcellus_egsp/index.htm.)

Piotrowski, R.G., and Krajewski, S.A., 1977a, Preliminary stratigraphic cross section $\left(\mathrm{C}_{4}-\mathrm{D}_{4}\right)$ showing radioactive black shale zones and sandstones in the middle and upper Devonian, western Pennsylvania: U.S. Department of Energy Morgantown Energy Technology Center, Eastern Gas Shales Project Series 5, 2 sheets.

Piotrowski, R.G., and Krajewski, S.A., 1977b, Preliminary stratigraphic cross section $\left(\mathrm{B}_{1}-\mathrm{B}_{4}\right)$ showing radioactive black shale zones and sandstones in the middle and upper Devonian, western Pennsylvania: Department of Energy Morgantown Energy Technology Center Eastern Gas Shales Project Series 7, 2 sheets.
Pohn, H.A., 2000, Lateral ramps in the folded Appalachians and in overthrust belts worldwide-A fundamental element of thrust-belt architecture: U.S. Geological Survey Bulletin 2163, 71 p. (Also available at http://pubs.er.usgs. gov/publication/b2163.)

Pohn, H.A., and Purdy, T.L., 1988, Disturbed zones; Indicators of subsurface faults and possible hydrocarbon traps in the Valley and Ridge and Appalachian Plateau provinces of Pennsylvania, Maryland, Virginia, and West Virginia, chap. C of Schultz, A.P., ed., Evolution of sedimentary basins: U.S. Geological Survey Bulletin 1839-A-D, p. C1-C11. (Also available at http://pubs.er.usgs.gov/publication/ b1839AD.)

Rader, E.K., and Evans, N.H., eds., 1993, Geologic map of Virginia; expanded explanation: Virginia Division of Mineral Resources, $80 \mathrm{p}$.

Rader, E.K., and Gathright, T.M., II, comps., 2001, Geologic map of the Front Royal $30 \times 60$ minute quadrangle: Portions of Clarke, Page, Rockingham, Shenandoah, and Warren Counties, Virginia: Virginia Division of Mineral Resources Publication 162, 1 sheet, scale 1:100,000. (Also available at $h t t p: / / w w w . d m m e . v i r g i n i a . g o v / c o m m e r c e d o c s /$ PUB_162.pdf.)

Rader, E.K., and Wilkes, G.P., comps., 2001, Geologic map of the Virginia portion of the Staunton $30 \times 60$ minute quadrangle: Virginia Division of Mineral Resources Publication

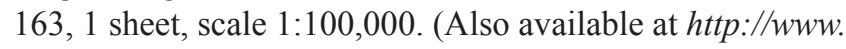
dmme.virginia.gov/commercedocs/PUB_163.pdf.)

Rader, E.K., McDowell, R.C., Gathright, T.M., II, and Orndorff, R.C., 2001, Geologic map of the Virginia portion of the Winchester $30 \times 60$ minute quadrangle: Virginia Division of Mineral Resources Publication 161, 1 sheet, scale 1:100,000. (Also available at $h t t p: / / w w w . d m m e . v i r g i n i a . g o v /$ commercedocs/PUB_161.pdf.)

Rich, J.L., 1934, Mechanics of low-angle overthrust faulting as illustrated by Cumberland thrust block, Virginia, Kentucky, and Tennessee: American Association of Petroleum Geologists Bulletin, v. 18, no. 12, p. 1584-1596. (Also available at http://archives.datapages.com/data/bulletns/1931-37/data/ pg/0018/0012/1550/1584.htm.)

Rodgers, John, 1949, Evolution of thought on structure of middle and southern Appalachians: American Association of Petroleum Geologists Bulletin v. 33, no. 10, p. 1643-1654. (Also available at http://archives.datapages.com/data/ bulletns/1949-52/data/pg/0033/0010/1600/1643.htm.)

Rodgers, John, 1963, Mechanics of Appalachian foreland folding in Pennsylvania and West Virginia: American Association of Petroleum Geologists Bulletin v. 47, no. 8, p. 15271536. (Also available at http://archives.datapages.com/data/ bulletns/1961-64/data/pg/0047/0008/1500/1527.htm.) 
Roen, J.B., 1984, Geology of the Devonian black shales of the Appalachian Basin: Organic Geochemistry v. 5, no. 4, p. 241-254, doi:10.1016/0146-6380(84)90011-1.

Roen, J.B., and de Witt, Wallace, Jr., 1984, Stratigraphic framework of the Devonian black shales of the Appalachian basin: U.S. Geological Survey Open-File Report 84-111, 71 p. (Also available at http://pubs.er.usgs.gov/publication/ ofr 84111 .)

Schultz, A.P., 1997, Geology of the Broadtop Synclinorium in the Winchester $30^{\prime} \times 60^{\prime}$ quadrangle, West Virginia: U.S. Geological Survey Open-File Report 97-143, 42 p., 1 pl., scale 1:100,000. (Also available at http://pubs.er.usgs.gov/ usgspubs/ofr/ofr97143.)

Schwietering, J.F., 1980, Preliminary cross section $\left(\mathrm{C}^{\left.-\mathrm{C}^{\prime}\right)}\right.$ of middle and upper Devonian in West Virginia: Department of Energy Morgantown Energy Technology Center, Eastern Gas Shales Project (EGSP) Series 210, 2 sheets.

Shumaker, R.C., 1980, Porous fracture facies in the Devonian shales of eastern Kentucky and West Virginia, in Wheeler, R.L., and Dean, C.S., eds., Proceedings, Western limits of detachment and related structures in the Appalachian foreland; Southeastern Section Geological Society of America meeting, Chattanooga, Tenn., April 6, 1978: U.S. Department of Energy Report DOE/METC/SP-80/23, p. 124-132. (Also available at http://www.netl.doe.gov/kmd/cds/disk7/ disk1/EGS\%5CProceedings, \%20Western\%20Limits\%20 of\%20Detachment\%20\&\%20Related\%20Structur.pdf.)

Smith, G.J., Jacobi, R.D., Loewenstein, Stu, and Seever, J.L., 2009, The influence of basement structures on Devonian black shale thicknesses in the northern Appalachian foreland basin [abs.], in AAPG annual convention abstracts, Denver, Colo., June 7-9, 2009: Tulsa, Okla., American Association of Petroleum Geologists, 1 CD-ROM. (Also available at http://aapg09.mapyourshow.com/2_1/sessions/ session.cfm?ScheduledSessionID=1626.)

Smith, L.B., and Leone, James, 2010, Integrated characterization of Utica and Marcellus black shale gas plays, New York State, in AAPG annual convention abstracts, New Orleans, La., April 11-14, 2010: Tulsa, Okla., American Association of Petroleum Geologists, 36 p., 1 CD-ROM. (Also available at http://www.searchanddiscovery.com/ documents/2010/50289smith/ndx_smith.pdf.)

Southworth, C.S., 1986, Side-looking airborne radar image map showing cross-strike structural discontinuities and lineaments of the central Appalachians: U.S. Geological Survey Miscellaneous Field Studies Map MF-1891, 14 p., 1 sheet. (Also available at http://pubs.er.usgs.gov/ publication/mf1891.)
U.S. Geological Survey, 2011, Devonian Marcellus Shale assessment units: U.S. Geological Survey database accessed June 8, 2012, at http://energy.usgs.gov/ OilGas/AssessmentsData/NationalOilGasAssessment/ USBasinSummaries. aspx? theTab $=$ dataTab\&provcode $=5067$

Virginia Division of Gas and Oil, 2010, Division of Gas and Oil: Virginia Division of Oil and Gas Web page accessed June 11, 2013, at http://www.dmme.virginia.gov/DGO/ DgoLandingPage.shtml.

Watney, W.L., Olea, R.A., and Davis, J.C., 1999, Regional stratigraphic analysis of a Pennsylvanian carbonate shelf and margin in Kansas, in Transactions, American Association of Petroleum Geologists Mid-Continent Section Meeting, Wichita, Kans., August 29-31, 1999: Lawrence, Kans., Kansas Geological Survey, p. 52-62, http://www.kgs.ku.edu/ Conferences/midcont99/watney1.html.

West Virginia Geological and Economic Survey, 2010, Pipeline Plus: West Virginia Geological and Economic Survey database accessed April 1, 2013 at http://www.wvgs.wvnet. edu/pipe2/OGWISHelp.aspx.

Wheeler, R.L., 1980, Cross-strike structural discontinuities; Possible exploration tool for natural gas in Appalachian overthrust belt: American Association of Petroleum Geologists Bulletin, v. 64, no. 12, p. 2166-2178. (Also available at http://archives.datapages.com/data/bulletns/1980-81/ data/pg/0064/0012/2150/2166.htm.)

Wheeler, R.L., 1983, Stratigraphic evidence for Devonian tectonism on lineaments at Allegheny front, West VirginiaSupporting material: U.S. Geological Survey Open-File Report 83-243, 25 p. (Also available at http://pubs.er.usgs. gov/publication/ofr83243.)

Wheeler, R.L., Winslow, Margaret, Horne, R.R., Dean, Stuart, Kulander, Byron Drahovzal, J.A., Gold, D.P., Gilbert, O.E., Jr., Werner, Eberhard, Sites, Roy, and Perry, W.J., Jr., 1979, Cross-strike structural discontinuities in thrust belts, mostly Appalachian: Southeastern Geology, v. 20, no. 3, p. 193-203.

Wilson, T.H., 1980, Cross-strike structural discontinuities; Tear faults and transfer zones in the central Appalachians of West Virginia: Morgantown, W. Va., West Virginia University, Department of Geology and Geography, 147 p. [Prepared under contract to U.S. Department of Energy, Morgantown Energy Technology Center Report DE-AC2176ET12138.]

Wilson, T.H., and Shumaker, R.C., 1992, Broad Top thrust sheet; An extensive blind thrust in the central Appalachians: American Association of Petroleum Geologists Bulletin, v. 76, no. 9, p. 1310-1324. (Also available at http://techplace.datapages.com/data/bulletns/1992-93/ data/pg/0076/0009/0000/1310.htm.) 
Manuscript approved on July 1, 2013

For additional information regarding this publication, contact:

Center Director, Eastern Energy Resources

Science Center

U.S. Geological Survey

12201 Sunrise Valley Drive

956 National Center

Reston, VA 20192

(703) 648-6401

Or visit the Eastern Energy Resources Science

Center Web site at:

http://energy.usgs.gov/Generallnfo/

ScienceCenters/Eastern.aspx

Prepared by USGS Science Publishing Network staff: James E. Banton, layout

Jeffrey Hartley, cartographer/illustrator

Elizabeth D. Koozmin, editor 



\section{这}

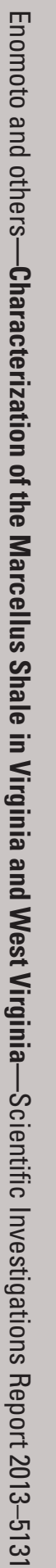

